\title{
Dissolution of Metals from Biosolid-Treated Soils by Organic Acid Mixtures
}

\author{
Won-Pyo Park, ${ }^{1}$ Bon-Jun Koo, ${ }^{1,2}$ Andrew C. Chang, ${ }^{2}$ Thomas E. Ferko, \\ Jonathan R. Parker, ${ }^{1}$ Tracy H. Ward, ${ }^{1}$ Stephanie V. Lara, ${ }^{1}$ and Chau M. Nguyen ${ }^{1}$ \\ ${ }^{1}$ Department of Natural and Mathematical Sciences, California Baptist University, Riverside, CA 92504-3297, USA \\ ${ }^{2}$ Department of Environmental Sciences, University of California, Riverside, CA 92521-0001, USA
}

Correspondence should be addressed to Bon-Jun Koo; bonjunkoo@calbaptist.edu

Received 1 December 2015; Revised 7 March 2016; Accepted 21 March 2016

Academic Editor: Bernardino Chiaia

Copyright (C) 2016 Won-Pyo Park et al. This is an open access article distributed under the Creative Commons Attribution License, which permits unrestricted use, distribution, and reproduction in any medium, provided the original work is properly cited.

Results for the solubilization of metals from biosolid- (BSL-) treated soils by simulated organic acid-based synthetic root exudates (OA mixtures) of differing composition and concentrations are presented. This study used two BSL-treated Romona soils and a BSL-free Romona soil control that were collected from experimental plots of a long-term BSL land application experiment. Results indicate that the solubility of metals in a BSL-treated soil with 0.01 and $0.1 \mathrm{M}$ OA mixtures was significantly higher than that of $0.001 \mathrm{M}$ concentrations. Differences in composition of OAs caused by BSL treatment and the length of growing periods did not affect the solubility of metals. There were no significant differences in organic composition and metals extracted for plants grown at $2,4,8,12$, and 16 weeks. The amount of metals extracted tended to decrease with the increase of the $\mathrm{pH}$. Results of metal dissolution kinetics indicate two-stage metal dissolution. A rapid dissolution of metals occurred in the first 15 minutes. For $\mathrm{Cd}, \mathrm{Cu}, \mathrm{Ni}$, and $\mathrm{Zn}$, approximately $60-70 \%$ of the metals were released in the first 15 minutes while the initial releases for $\mathrm{Cr}$ and $\mathrm{Pb}$ were approximately $30 \%$ of the total. It was then followed by a slow but steady release of additional metals over 48 hours.

\section{Introduction}

Organic acids (OAs) provide attractive options for extracting agents not only because they are biodegradable $[1,2]$, but also because they are able to extract metal contaminants from soils at mildly acidic conditions ( $\mathrm{pH} 3-5)$. OAs found in root exudates, such as citric, oxalic, tartaric, and acetic acids, are capable of forming complexes with $\mathrm{Cu}, \mathrm{Zn}, \mathrm{Pb}$, and $\mathrm{Co}$ ions in solutions [3-8] and enhancing their mobilization and uptake by plants [9-12]. Römheld and Awad [13] showed that plants grown on low Fe nutrient mediums in contaminated soil had a higher uptake of $\mathrm{Fe}, \mathrm{Zn}, \mathrm{Ni}$, and $\mathrm{Cd}$ (up to 200\%) than control plants in adequate $\mathrm{Fe}$ nutrient mediums [14]. Various OAs and/or their salts were tested against two metal chelating agents (EDTA and DTPA) for their potential effects in the remediation of loam and sandy clay loam polluted by heavy metals $[15,16]$. Experimental evidence shows that OAs added to humic macromolecules induced the release of adsorbed metal ions $[17,18]$. In near neutral and neutral aqueous solutions, OAs are readily dissociated. The negatively charged OA ligands are capable of forming complexes with metals (e.g., $\mathrm{Mn}, \mathrm{Fe}$, and $\mathrm{Zn}$ ) in solutions, increasing their availability to plants $[11,19,20]$.

The extent of complexation depends on the characteristics of the OAs involved (number and proximity of carboxylic groups), their concentrations, types of metal, and the $\mathrm{pH}$ of the soil [21]. Organic acids with only one carboxyl group, such as acetic, formic, and lactic acids, have less metal complexing ability than malic and oxalic acids, which are frequently found OAs in soils that have a high affinity for complexing metals $[14,22,23]$. The ability of OAs to complex metals is also dependent on $\mathrm{pH}$ [24]. For instance, the complexation of Fe by malic and oxalic acids is highly dependent on soil $\mathrm{pH}$, with little or no complexation at $\mathrm{pH}>7.0$ [25]. In addition, malic and oxalic acids have the tendency to precipitate in the presence of $\mathrm{Ca}^{2+}$, thus reducing their potential to complex with other metals [26]. When compared with rainwater alone, OAs are able to double or even quadruple mineral dissolution 
rates. The extent of the chemical reactions, however, is dependent on mineral type, $\mathrm{pH}$, and OA type [22]. Jones and Kochian [23] reported that the presence of OAs increases the dissolution of $\mathrm{Fe}$ and $\mathrm{Al}$ oxyhydroxides.

OAs may be adsorbed onto the hydroxyaluminummontmorillonite (HyA-Mt) complex. Cambier and Sposito [27] concluded that the HyA-Mt complex is stable at $4<\mathrm{pH}$ $<5.5$, and only external HyA polycations could react with citrate. Janssen et al. [28] noted that citrate did not appear to be adsorbed on the Al-OH groups of the HyA-Mt complex; instead it is adsorbed at the edge of the clay [29]. Sakurai and Huang [30] studied the effect of oxalate on the adsorption of $\mathrm{Cd}$ by montmorillonite (Mt) and HyA-Mt complex at $\mathrm{pH} 5$. The reaction was very rapid and virtually completed within 10 minutes. The presence of oxalate markedly interfered with $\mathrm{Cd}$ adsorption on clays, especially on the montmorillonite. Taniguchi et al. [31] investigated the adsorption phenomena of Cd on hydroxyaluminosilicate- (HAS-) montmorillonite (Mt) and HyA-Mt complexes as influenced by oxalate and citrate. They concluded that the optimal concentrations of oxalate and citrate for $\mathrm{Cd}$ adsorption depended on the form of $\mathrm{Cd}$ ions in the solution.

Early research by Eaton [32] showed that plant roots absorbed $\mathrm{P}$ and Fe from "water insoluble" $\mathrm{P}$ and Fe containing minerals present in the growth medium. Jenny and Overstreet [33] proposed that reactions between root and solid phase minerals that were in direct contact or in close proximity would facilitate plant absorption of sparingly soluble mineral nutrients in soils. Recent studies have demonstrated that root exudates, which contain OAs, play a significant role in the solubilization of metals in soil $[5,11,34]$. In BSL, metals are present almost entirely in solid phases. Upon land application, BSL-borne metals remain largely in their original solid phases in BSL-treated soils [35]. Mobilization of metals by OAs in root exudates would be the most significant pathway through which plant absorption of metals from BSLtreated soils occurs [36]. The total amount of bioavailable metals in BSL-treated soils can be estimated by extracting the soils using OAs found in the rhizosphere of plants grown on BSL-treated medium. It follows that the rate of metal availability for plants would be in proportion to the rate of metal dissolution in the OA mixture [37].

The $\mathrm{pH}$ of the rhizosphere is also important in determining metal and nutrient mobilization and uptake. It also affects microbial activity in the vicinity of the root. Root induced $\mathrm{pH}$ change in the rhizosphere is a known phenomenon $[38,39]$ and has an effect on the availability or solubility of nutrients such as $\mathrm{P}, \mathrm{Fe}, \mathrm{Mn}, \mathrm{Zn}, \mathrm{Cu}$, and $\mathrm{Al}$ [40]. Rhizosphere $\mathrm{pH}$ may differ from the bulk soil $\mathrm{pH}$ by more than 2 units [41]. Buffer capacities of soil and root activity are the main factors influencing $\mathrm{pH}$ at the soil-root interface [42]. Several hypotheses have been postulated to explain the different abilities of plant species in affecting rhizosphere $\mathrm{pH}$ : these include differences in root exudation and respiration patterns and differences in cation/anion uptake rates [43]. Since plant roots acquire most mineral nutrients and metals as ions, imbalances between the absorption of cations and anions result in roots' excretion of compensating $\mathrm{H}^{+}$or $\mathrm{OH}^{-}$ions into the soil in rhizosphere, to prevent changes
TABLE 1: Chemical properties of the soil used for the experiment.

\begin{tabular}{|c|c|c|c|c|c|c|c|}
\hline \multirow{2}{*}{$\begin{array}{l}\text { Biosolid } \\
\text { treatment }^{\dagger}\end{array}$} & \multirow{2}{*}{$\mathrm{pH}^{\ddagger}$} & \multicolumn{6}{|c|}{ Total concentration $\left(\mathrm{mg} \mathrm{kg}^{-1}\right)$} \\
\hline & & $\mathrm{Cd}$ & $\mathrm{Cr}$ & $\mathrm{Cu}$ & $\mathrm{Ni}$ & $\mathrm{Pb}$ & $\mathrm{Zn}$ \\
\hline Control & 7.7 & 0.5 & 37 & 105 & 24 & 25 & 95 \\
\hline $135 \mathrm{Mg} \mathrm{ha}^{-1}$ & 6.9 & 11 & 243 & 188 & 88 & 120 & 559 \\
\hline $1,080 \mathrm{Mg} \mathrm{ha}^{-1}$ & 6.1 & 26 & 596 & 478 & 215 & 396 & 1466 \\
\hline
\end{tabular}

${ }^{\dagger}$ Obtained at Moreno Field Station of the University of California, Riverside, CA. From 1976 through 1981, composted biosolids were applied at dry weight rates of 0 (control), 22.5, and $180 \mathrm{Mg} \mathrm{ha}^{-1} \mathrm{yr}^{-1}$, respectively.

${ }^{\ddagger} 1: 1 \mathrm{w} / \mathrm{v}$ ratio.

in the electroneutrality of the root tissues [44]. Gollany and Schumacher [45] conducted a growth chamber study to characterize patterns of $\mathrm{pH}$ change within the rhizosphere of plants and the $\mathrm{pH}$ at different root zones was measured by a microelectrode at $1,2,3$, and $4 \mathrm{~mm}$ distances from the root surface. They reported that the $\mathrm{pH}$ decreased to 4.82 and 4.95 in the rhizosphere around elongation and meristematic zones, respectively, compared to the control ( $\mathrm{pH}=7.6)$ without plants.

The objectives of this study were the following:

(1) To use an OA mixture as a substitute for actual OAs in root exudates to solubilize metals in BSL-treated soils.

(2) To test the solubilization of metals in BSL-treated soils by the different concentrations of the OA mixture of corn (Zea mays L.).

In order to meet these objectives, the researchers needed to assess OA mixture-specific metal solubility and dissolution rate constants of BSL-treated soils.

\section{Materials and Methods}

2.1. Chemical Properties of the Soils. Two BSL-treated Romona soils and the BSL-free Romona soil control from the field plots of a long-term BSL land application experiment were used [46]. These experiment plots were established in 1976 on a Romona sandy loam soil (fine-loamy, mixed, thermic Typic Haploxeralf) located in the Moreno Field Station of the University of California, Riverside. The Nu-earth BSL used throughout the experiment contained an average of $40,600,475,250$, and $3,547 \mathrm{mg} \mathrm{kg}^{-1}$ of $\mathrm{Cd}, \mathrm{Cr}, \mathrm{Cu}, \mathrm{Ni}$, and Zn, respectively. From 1976 through 1981, composted BSL were applied at a rate of 0 (control), 22.5, 45, 90, and $180 \mathrm{Mg} \mathrm{ha}^{-1} \mathrm{yr}^{-1}$ dry weight. The entire experimental fields were cultivated for 10 years (1982-1991) following the termination of BSL application. Soil collected in 1991 from the control, 22.5, and $180 \mathrm{Mg} \mathrm{ha}^{-1} \mathrm{yr}^{-1}$ treatments was used. Soil samples were air-dried and ground to pass through a $2 \mathrm{~mm}$ sieve, homogenized, and stored for subsequent analysis. The chemical properties of the selected soils used in the study are presented in Table 1. For metal determination, aliquots of soil samples were digested in Teflon Parr bombs by a $\mathrm{HNO}_{3}$ microwave digestion procedure $(0.3 \mathrm{~g}$ soil with a mixture of $1.0 \mathrm{~mL} \mathrm{H}_{2} \mathrm{O}+4.5 \mathrm{~mL}$ concentrated $\mathrm{HNO}_{3}+1.5 \mathrm{~mL}$ concentrated $\mathrm{HCl}$, in a $120 \mathrm{~mL}$ Teflon digestion vessel for 20 minutes and with maximum pressure of $484 \mathrm{kPa}$ ) [47]. 
2.2. Release and Analysis of the Metals. One gram of the soils was mixed with $10 \mathrm{~mL}$ of $\mathrm{OA}$ mixtures in $50 \mathrm{~mL}$ Teflon test tubes. The contents were shaken and allowed to equilibrate at $298^{\circ} \mathrm{K}$ using a rotary mixer, SA-12 Motor Speed Control (B \& B Motor and Control Corp., Long Island City, NY), which rotated the capped test tubes head to tail at approximately $1 \mathrm{rpm}$ for 48 hours. The speed of rotation was maintained constant in all treatments. One $\mathrm{mL}$ of chloroform was added to each test tube to control microbial activity and prevent decomposition of $\mathrm{OA}$ mixtures during equilibration. The $\mathrm{pH}$ and EC of the system in the beginning and at the end of the reaction period were monitored and attempts were made to keep the $\mathrm{pH}$ constant. Three OA mixture concentrations $0.001,0.01$, and $0.1 \mathrm{M}$ in $13.5 \mathrm{mM} \mathrm{Ca}\left(\mathrm{NO}_{3}\right)_{2}$ along with a $13.5 \mathrm{mM} \mathrm{Ca}\left(\mathrm{NO}_{3}\right)_{2}$ blank were tested. Each treatment combination was replicated two times. After equilibration, the soil suspensions were centrifuged for 20 minutes at $8,000 \mathrm{rpm}$ to separate the solution and solid phases. The solution phase was passed through a $0.45 \mu \mathrm{m}$ filter paper into $25 \mathrm{~mL}$ volumetric flasks. The filtrates were acidified with $0.25 \mathrm{~mL}$ of concentrated $\mathrm{HNO}_{3}$. The metal contents of the supernatants were determined using Inductively Coupled Plasma Optical Emission Spectroscopy (ICP-OES) and Atomic Absorption Spectrophotometry (AAS) [47]. The ICP-OES system was OPTIMA $3000 \mathrm{~V}$ (Perkin-Elmer, Norwalk, CT, USA) with AS-91 Autosampler and WinLab ${ }^{\mathrm{TM}}$ software for the optima family of ICP-OES. Another instrument utilized was the Perkin-Elmer Analyst 800 Atomic Absorption Spectrometer (Perkin-Elmer, Bodenseewerk, Germany) with AS-800 Autosampler. The same experimental setup was used for the batch metal dissolution kinetics. The metal concentrations at $0,0.25,0.5,1,2,4,8,24$, and 48 hours were determined for the kinetic studies.

2.3. Statistical Analysis. All experiments were repeated. Between-group differences were determined by one-way analysis of variance (ANOVA), followed by StudentNewman-Keuls test using a probability level of $P<0.05$ in all cases. Tests were performed with SigmaStat 4.01 Software.

\section{Results and Discussion}

3.1. Formulation of Organic Acid Mixtures. Organic acids in rhizosphere are difficult to collect because the volume produced is limited and the components of the root exudates are readily biodegradable. To evaluate the OAs' ability in the rhizosphere to solubilize metals in the soils, a large amount of root exudates must be collected. Because of the difficulty in collecting and preserving root exudates, it is imperative that an OA-based synthetic root exudate (OA mixture) be formulated.

The OA mixture should contain the primary chemical components responsible for metal complex formation and should be in the concentration and $\mathrm{pH}$ ranges commonly observed in the rhizosphere. In addition, the OA mixtures should also be prepared under the same background chemical matrix of the soil solution. In this manner, the OA mixture would exhibit comparable ability of reacting with metals as the actual root exudates.
TABLE 2: Amounts of Cd extracted by organic acid (OA) mixtures of various compositions and concentrations ${ }^{\dagger}$.

\begin{tabular}{|c|c|c|c|}
\hline \multirow{2}{*}{ OA concentration } & \multirow{2}{*}{$\begin{array}{c}\text { OA } \\
\text { composition }^{\ddagger}\end{array}$} & \multicolumn{2}{|c|}{ Cd concentration $\left(\mathrm{mg} \mathrm{kg}^{-1}\right)$} \\
\hline & & Biosolid & Standard \\
\hline \multirow{5}{*}{$0.1 \mathrm{M}$} & 2nd & $2.11^{\mathrm{Ba}}$ & $1.86^{\mathrm{Ba}}$ \\
\hline & 4 th & $2.36^{\mathrm{Aa}}$ & $2.58^{\mathrm{Aa}}$ \\
\hline & 8th & $1.98^{\mathrm{Ba}}$ & $1.63^{\mathrm{Ba}}$ \\
\hline & 12th & $1.79^{\mathrm{Ba}}$ & $1.60^{\mathrm{Ba}}$ \\
\hline & 16 th & $1.71^{\mathrm{Ba}}$ & $1.62^{\mathrm{Ba}}$ \\
\hline \multirow{5}{*}{$0.01 \mathrm{M}$} & 2nd & $0.39^{\mathrm{Aa}}$ & $0.31^{\mathrm{Aa}}$ \\
\hline & 4 th & $0.41^{\mathrm{Aa}}$ & $0.43^{\mathrm{Aa}}$ \\
\hline & 8 th & $0.44^{\mathrm{Aa}}$ & $0.35^{\mathrm{Aa}}$ \\
\hline & 12 th & $0.47^{\mathrm{Aa}}$ & $0.37^{\mathrm{Aa}}$ \\
\hline & 16 th & $0.51^{\mathrm{Aa}}$ & $0.43^{\mathrm{Aa}}$ \\
\hline \multirow{5}{*}{$0.001 \mathrm{M}$} & 2nd & $0.29^{\mathrm{Aa}}$ & $0.20^{\mathrm{Aa}}$ \\
\hline & 4 th & $0.32^{\mathrm{Aa}}$ & $0.24^{\mathrm{Aa}}$ \\
\hline & 8th & $0.36^{\mathrm{Aa}}$ & $0.32^{\mathrm{Aa}}$ \\
\hline & 12th & $0.29^{\mathrm{Aa}}$ & $0.23^{\mathrm{Aa}}$ \\
\hline & 16th & $0.30^{\mathrm{Aa}}$ & $0.29^{\mathrm{Aa}}$ \\
\hline $\begin{array}{l}13.5 \mathrm{mM} \\
\mathrm{Ca}\left(\mathrm{NO}_{3}\right)_{2}\end{array}$ & Not applicable & \multicolumn{2}{|c|}{0.10} \\
\hline
\end{tabular}

${ }^{\dagger}$ Values represent means of four replicates. The differences of $\mathrm{Cd}$ concentrations among the OA compositions of growth periods were tested by one-way ANOVA. In each column of each organic concentration, values followed by the same uppercase letter were not significantly different at $P<0.05$. The differences of the Cd concentrations between standard (STD) and biosolid (BSL) treatments were tested by Student-Newman-Keuls test. Each pair of Cd concentrations followed by the same lowercase letter was not significantly different at $P<0.05$.

${ }^{\ddagger}$ Compositions corresponding to OAs recovered from STD and BSL-treated medium of corn at $2 \mathrm{nd}, 4 \mathrm{th}, 8 \mathrm{th}, 12 \mathrm{th}$, and 16 th weeks of growth.

To simulate OAs in root exudates, an OA mixture of similar composition to the root exudate composition was formulated. A series of experiments were conducted to test the effect of OA compositions, the total concentration of metals, and the concentration of OAs in the dissolution of metals in the BSL-treated soils. The amount of metals extracted by the OA mixtures, representing compositions of OAs recovered from the rhizosphere of corn grown on BSLtreated medium and the standard (STD) sand medium [34], was illustrated by the Cd extractions summarized in Table 2 . The differences of metals extracted due to the compositions representing OAs at 2, 4, 8, 12, and 16 weeks of plant growth were not significant at $P<0.05$ and the differences due to OAs of STD and BSL-treated medium were not significant at $P<0.05$. The trends were similar for other metals extracted. The data were then pooled to test the differences in metal extractions due to the concentrations of OA mixtures. They were significant at $P<0.05$. Based on the results, the OA mixture was formulated.

3.1.1. Composition and Concentration of OAs. Although the OA compositions of the root exudates recovered from plants were grown for various lengths of time from different plant species, they did not vary significantly under our system 

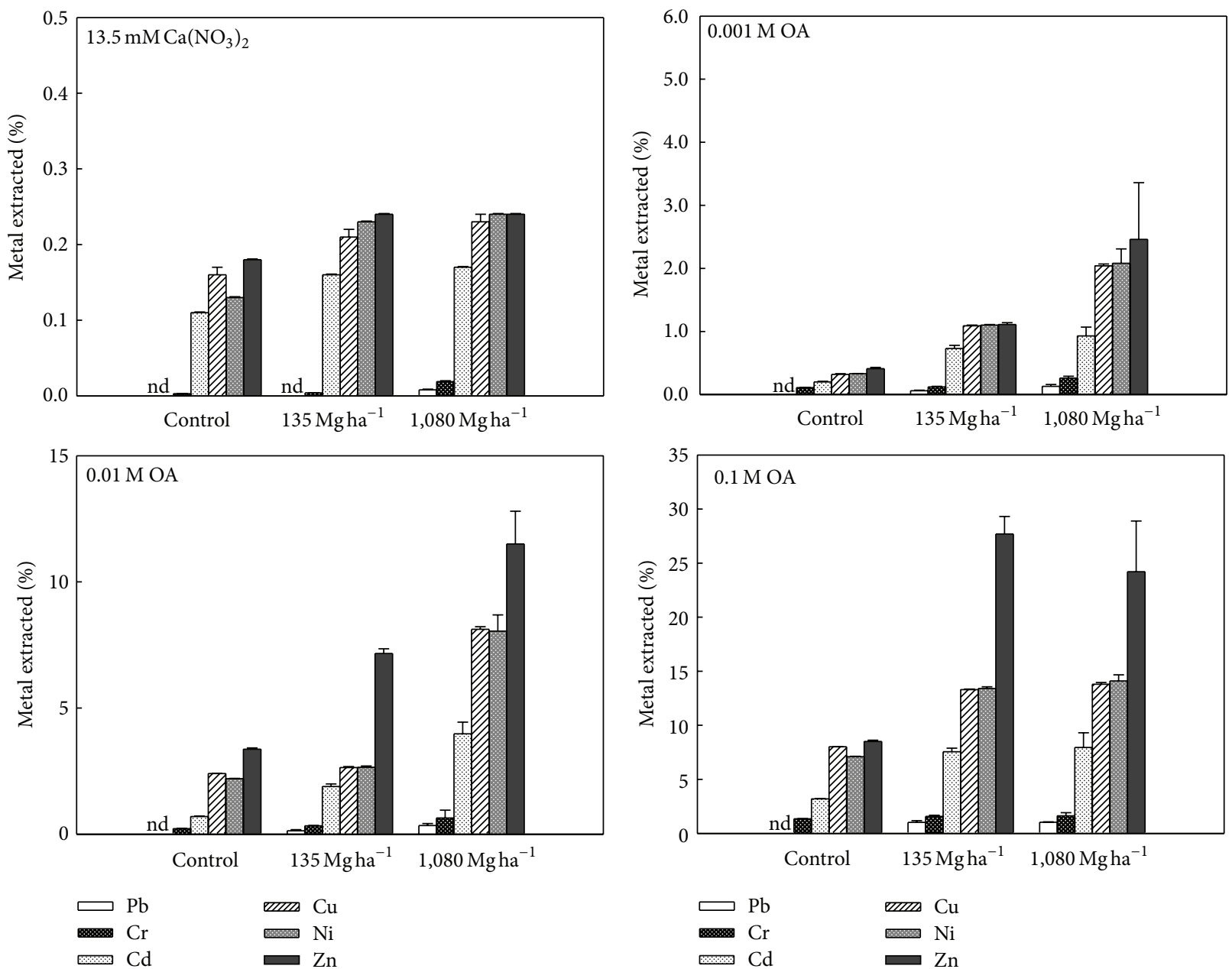

Figure 1: Percentages of metal extracted (means \pm SD where $n=4$ ) from control and biosolid-treated Romona soil by the organic acid mixtures. Obtained at Moreno Field Station of the University of California, Riverside, CA. From 1976 through 1981, composted biosolids were applied at dry weight rates of 0 (control), 22.5, and $180 \mathrm{Mg} \mathrm{ha}^{-1} \mathrm{yr}^{-1}$, respectively. Some of the observations were below detection limits (nd) of the AAS for $\mathrm{Pb}=0.001 \mathrm{mg} \mathrm{kg}^{-1}$.

[34]. The OA mixture composition was taken as the average composition of OAs recovered from the rhizosphere of corn grown on BSL-treated medium for 16 weeks and summarized in Table 3.

Figure 1 summarizes the amounts of metals extracted by OA mixtures at concentrations of $0.001,0.01$, and $0.1 \mathrm{M}$. The experimental results indicate that the concentrations of the OA mixtures significantly affect the amount of metals extracted. The amount of metals extracted by the OA mixtures was considerably greater than that of the neutral electrolyte solution, $13.5 \mathrm{mM}$ of $\mathrm{Ca}\left(\mathrm{NO}_{3}\right)_{2}$, which was used to represent the background chemical matrix of the soil solution. Based on the moisture content of the rhizosphere and the amount of OAs recovered from the rhizosphere [34], the concentrations of OAs in the rhizosphere were estimated to be from 0.001 to $0.013 \mathrm{M}$ (Table 4). As the OAs are closely associated with root exudates, their concentrations are expected to be considerably higher near the root and soil interface and could approach $0.1 \mathrm{M}$.
TABLE 3: Mole fraction of organic acids collected in root exudates of corn.

\begin{tabular}{lcc}
\hline Organic acid & Molecular weight & Mole fraction ratio \\
\hline Acetic & 60.05 & 0.287 \\
Butyric & 88.11 & 0.209 \\
Glutaric & 132.12 & 0.004 \\
Lactic & 90.08 & 0.366 \\
Maleic & 116.07 & 0.042 \\
Oxalic & 90.04 & 0.043 \\
Propionic & 74.08 & 0.010 \\
Pyruvic & 88.06 & 0.0004 \\
Succinic & 118.09 & 0.006 \\
Tartaric & 150.09 & 0.032 \\
Valeric & 102.13 & 0.001 \\
\hline
\end{tabular}

Quantitative measurements of root exudates from plant roots indicate that $\mathrm{OA}$ concentrations as high as $50 \mathrm{mM}$ 
TABLE 4: Estimated solution concentrations (16-week average) of organic acid mixtures in root exudates of corn ${ }^{\dagger}$.

\begin{tabular}{lcccc}
\hline \multirow{2}{*}{ Treatment } & \multicolumn{4}{c}{ Estimated concentration (mM) } \\
& Standard (control) & \multicolumn{2}{c}{ Biosolid-treated } \\
& Mean & SD & Mean & SD \\
\hline Blank & 2.05 & 0.63 & 3.41 & 0.87 \\
Planted & 5.23 & 1.21 & 12.9 & 2.04 \\
\hline
\end{tabular}

${ }^{\dagger}$ All experiments performed in four replicates for each 2, 4, 8, 12, and 16 weeks. Values represent means and standard deviation of 20 replicates.

were found within $1 \mathrm{~mm}$ from the root surface [53], with typical concentrations in roots at $10-20 \mathrm{mM}$. For example, in corn, organic solutes present in root cells existed primarily as amino acids (10-20 mM) and sugars (90 mM) [54]. Generally, higher concentrations of OAs are expected in the rhizosphere soil compared to those in the bulk soil $[34,55]$. Soil microorganisms do not utilize the carboxylic acids, which play a significant role in complexing metal ions in soils as rapidly as the carbohydrates [3].

3.1.2. $p H$ of the Rhizosphere Soils. The rhizosphere typically extends $1-5 \mathrm{~mm}$ outward from the interface of the root and soil but the $\mathrm{pH}$ measurement is complicated. Instead of directly measuring the $\mathrm{pH}$ of the rhizosphere, it was deduced and estimated from data found in literature. Studies of the rhizosphere changes in $\mathrm{pH}$ along roots of crops and $\mathrm{pH}$ changes at different distances from roots are listed in Table 5.

Zhang and Pang [50] demonstrated that while $\mathrm{pH}$ was essentially uniform in unvegetated soil, $\mathrm{pH}$ was lower near the root tips than at other locations around the root in vegetated soil. The $\mathrm{pH}$ varied from 6.2 near the surface $(0.5 \mathrm{~cm}$ depth) to 4.99 at $6 \mathrm{~cm}$ below the soil surface.

It is apparent that $\mathrm{pH}$ at or near the root of living plants was altered by root exudation. It varied from $\mathrm{pH}=4-5$ at the soil-root interface and gradually varied to the level comparable to the $\mathrm{pH}$ of bulk soils over approximately $5 \mathrm{~mm}$ of distance. The $\mathrm{pH}=4.8$ was chosen as the $\mathrm{pH}$ for the synthetic root exudates based on the results of effects of $\mathrm{pH}$ on the dissolution of metals in the BSL-treated soils.

\subsection{Effects of $p H$ on the Dissolution of Metals in the Biosolid-} Treated Soils. The $\mathrm{pH}$ of the rhizosphere may vary from 4.0 to 8.0 (Table 5) and may affect the solubility of metals in the soil. The effects of $\mathrm{pH}$ on the dissolution of metals in BSLtreated soils by the OA mixture were determined. Based on the outcome of this experiment, the $\mathrm{pH}$ of the $\mathrm{OA}$ mixture was set at 4.8. A BSL-treated Romona soil $\left(135 \mathrm{Mg} \mathrm{ha}^{-1}\right)$ was extracted by the $0.01 \mathrm{M} \mathrm{OA}$ mixture and $13.5 \mathrm{mM} \mathrm{Ca}\left(\mathrm{NO}_{3}\right)_{2}$ that were adjusted to $\mathrm{pH}=4.5,5.5,6.5$, and 7.5.

The amounts of metals extracted tended to decrease with the increase of the $\mathrm{pH}$ and, at the same $\mathrm{pH}$ level, the OA mixture typically extracted more metals than the $13.5 \mathrm{mM}$ $\mathrm{Ca}\left(\mathrm{NO}_{3}\right)_{2}$ electrolyte solution (Figure 2). The extent of $\mathrm{pH}-$ induced changes in metal solubility was not substantial. Cadmium and zinc experienced by far the biggest decrease, from 0.04 to 0.02 and 2.3 to $1.1 \mathrm{mg} \mathrm{kg}^{-1}$, respectively, when $\mathrm{pH}$ of the extracting OA mixture increased from 4.5 to 7.5. The change in extractable $\mathrm{Cd}$ and $\mathrm{Zn}$ was larger from $\mathrm{pH}=4.5$ to 5.5 than from 6.5 to 7.5. Under the same circumstance, the $\mathrm{Cr}$ extracted decreased from approximately 0.1 to $0.08 \mathrm{mg} \mathrm{kg}^{-1}$. Statistical tests indicated that metals extracted at $\mathrm{pH}=$ 4.5 were not significantly different from the corresponding metals extracted at $\mathrm{pH}=5.5$ (Figure 2).

In general, the holding capacity of soils for metals increases with increasing $\mathrm{pH}$. Exceptions are $\mathrm{Cr}$ and $\mathrm{Mo}$, which are commonly more mobile under alkaline conditions. Accordingly, a decrease in plant uptake of $\mathrm{Cu}, \mathrm{Mn}$, and $\mathrm{Zn}$ was observed when soil $\mathrm{pH}$ was increased $[56,57]$. The $\mathrm{pH}$ can be issued as the main driving factor of all the factors because it can affect the surface charge of layer silicate clays, $\mathrm{OM}$, and oxides of Fe and Al. In addition to the effect on the sorption of cations, which increases with increasing $\mathrm{pH}$, Fernández-Ramos et al. [58] reported that the adsorption of certain trace metals onto hydrous ferric oxide depends on $\mathrm{pH}$. The results correspond to our findings.

3.3. Metal Solubility by Organic Acid Mixtures. Metals in the soils were not readily extractable by the neutral electrolyte solution blank that contained $13.5 \mathrm{mM} \mathrm{Ca}\left(\mathrm{NO}_{3}\right)_{2}$ and, in general, less than $0.25 \%$ of any metals were solubilized (Figure 1).

For $\mathrm{Pb}$, the concentrations in the extracts of blank were below limits of quantification of AAS $\left(<0.001 \mathrm{mg} \mathrm{kg}^{-1}\right)$. For the control soil, the total metal concentrations and percent of metals extracted were considerably lower than those in BSLtreated soils.

In BSL-treated soils, the amount of metals extracted was proportional to the amount present in soils and the percentage of the total metals extracted from BSL-treated soils increased with the concentration of OA mixtures; however, the percentage of extraction did not appear to change significantly with the BSL loading when soils were extracted by the $0.1 \mathrm{M} \mathrm{OA}$ mixture. In general, $\mathrm{Cd}, \mathrm{Cu}, \mathrm{Ni}$, and $\mathrm{Zn}$ were more readily extractable by the OA mixtures (Figure 1) than $\mathrm{Cr}$ and $\mathrm{Pb}$. The least extractable $\mathrm{Pb}$ and $\mathrm{Cr}$ from the BSL-treated soils follow the general trend reported in the previous paper [34] because of their strong complexation with OM compounds [56] and more specifically the effective role of OM of BSL to serve as electron donors for the reduction of $\mathrm{Cr}(\mathrm{VI})$ to $\mathrm{Cr}(\mathrm{III})$ [59]. Metals extracted from BSL-treated soils were almost all from BSL. For instance, the amount of $\mathrm{Cd}$ extracted from control Romona soil by $13.5 \mathrm{mM} \mathrm{Ca}\left(\mathrm{NO}_{3}\right)_{2}$ was $0.0008 \mathrm{mg} \mathrm{kg}^{-1}$ (Figure 1) and the amount of Cd extracted from BSL-treated soil with the same electrolyte solution blank was $0.023 \mathrm{mg} \mathrm{kg}^{-1}$. We calculated that the amount of Cd extracted from BSL-treated soils is about $97 \%$ of the total extracted Cd.

3.4. Metal Dissolution Kinetics of Biosolid-Treated Soils by Organic Acid Mixtures. The batch equilibrium method was used to study the kinetics of metal dissolution in BSLtreated soils. The experimental procedures were similar to those previously described in the metal solubility study, with the exception that samples were equilibrated for time periods ranging from 15 minutes to 48 hours. When the BSLtreated soils $\left(1,080 \mathrm{Mg} \mathrm{ha}^{-1}\right)$ were equilibrated with $0.1 \mathrm{M} \mathrm{OA}$ 
TABLE 5: Reported pH ranges of rhizosphere.

\begin{tabular}{|c|c|c|c|}
\hline Plant & Genotype & pH range & Reference \\
\hline \multirow[t]{2}{*}{ Barley } & $\begin{array}{l}\text { Bowman } \\
\text { Primus II }\end{array}$ & $\begin{array}{l}6.2-7.6 \\
6.0-7.8\end{array}$ & $\begin{array}{l}\text { Gollany and Schumacher } \\
\text { [45] }\end{array}$ \\
\hline & Dorirumugi & $4.8-7.1$ & Youssef and Chino [42] \\
\hline \multirow[t]{2}{*}{ Corn } & $\begin{array}{l}\text { Pioneer-3737 } \\
\text { Pioneer-3732 } \\
\text { CM-37 }\end{array}$ & $\begin{array}{l}5.2-7.6 \\
5.2-7.6 \\
6.0-7.6\end{array}$ & $\begin{array}{l}\text { Gollany and Schumacher } \\
\text { [45] }\end{array}$ \\
\hline & - & $4.8-6.7$ & Fischer et al. [48] \\
\hline Clover & Trikkala & $6.2-7.1$ & Hinsinger and Gilkes [49] \\
\hline Daisy fleabane & - & $5.1-6.3$ & Zhang and Pang [50] \\
\hline Nectarine tree & Maxim & $5.3-8.2$ & Tagliavini et al. [36] \\
\hline Oat & $\begin{array}{l}\text { Hytest } \\
\text { SD } 84104\end{array}$ & $\begin{array}{l}6.0-7.6 \\
6.2-7.6 \\
\end{array}$ & $\begin{array}{l}\text { Gollany and Schumacher } \\
\text { [45] }\end{array}$ \\
\hline Rape & - & $5.7-6.4$ & Ruiz and Arvieu [25] \\
\hline Rye & Standard & $5.6-7.1$ & Hinsinger and Gilkes [49] \\
\hline Sordan & $\begin{array}{l}\text { S-757 } \\
\text { S-333 }\end{array}$ & $\begin{array}{l}6.0-7.6 \\
6.1-7.6 \\
\end{array}$ & $\begin{array}{l}\text { Gollany and Schumacher } \\
{[45]}\end{array}$ \\
\hline Sorghum & $\begin{array}{l}\text { SC-33-8-9EY } \\
\text { SC-118-15E }\end{array}$ & $\begin{array}{l}6.3-7.6 \\
6.6-7.6 \\
\end{array}$ & $\begin{array}{l}\text { Gollany and Schumacher } \\
{[45]}\end{array}$ \\
\hline \multirow[t]{4}{*}{ Soybean } & Hawkeye & $\begin{array}{l}5.5-7.1 \\
4.8-7.6\end{array}$ & $\begin{array}{l}\text { Römheld and Marschner } \\
\text { [51] } \\
\text { Gollany and Schumacher } \\
\text { [45] }\end{array}$ \\
\hline & PI-54169 & $5.8-7.6$ & $\begin{array}{l}\text { Gollany and Schumacher } \\
\text { [45] }\end{array}$ \\
\hline & Toyosuzu & $5.1-7.0$ & Youssef and Chino [42] \\
\hline & - & $4.7-7.1$ & Riley and Barber [52] \\
\hline
\end{tabular}

mixture, the amount of BSL-borne metals solubilized in the OA mixtures increased from 1.67 to $2.48,1.46$ to $5.04,20.3$ to $33.4,16.1$ to $24.1,0.77$ to 2.33 , and 205 to $282 \mathrm{mg} \mathrm{kg}^{-1}$ for Cd, $\mathrm{Cr}, \mathrm{Cu}, \mathrm{Ni}, \mathrm{Pb}$, and $\mathrm{Zn}$, respectively, when equilibration time increased from 15 minutes to 48 hours (Tables 6-8).

The percentages of total BSL-borne metals extracted were $13.8,1.63,7.95,14.1,1.03$, and $24.2 \%$ for $\mathrm{Cd}, \mathrm{Cr}, \mathrm{Cu}, \mathrm{Ni}, \mathrm{Pb}$, and $\mathrm{Zn}$, respectively. If OAs are responsible for converting metals in solid phases into plant available forms, the amount and rate of the metals' solubilization would be indicative of the metals' availability to plants.

The metal dissolution kinetics data was plotted as a fraction of the total dissolved metals $\left(C_{t} / C_{48}\right.$, based on 48 hours' equilibration, $\left.C_{48}\right)$ that was found at time $t\left(C_{t}\right)$ (Figure 3). The patterns for dissolution in the OA mixtures were essentially the same for all metals. When the BSL-treated soils were equilibrated with the $0.1 \mathrm{M}$ OA mixture, there appeared to be an immediate and rapid release of metals from the soil. The amount of $\mathrm{Cd}, \mathrm{Cu}, \mathrm{Ni}$, and $\mathrm{Zn}$ solubilized in the first 15 minutes $\left(C_{0.25}\right)$ accounted for approximately $60-75 \%$ of the total dissolved metals. For $\mathrm{Cr}$ and $\mathrm{Pb}$, approximately 8 hours was needed to dissolve $60-70 \%$ of the total soluble metals. After 15 minutes, the dissolution of metals slowly reached the steady state over a period of 48 hours. When the concentrations of the $\mathrm{OA}$ mixtures were $0.001 \mathrm{M}$ and $0.01 \mathrm{M}$, the dissolution behavior of metals in BSL-treated soils exhibited the same pattern as those of $0.1 \mathrm{M}$ OA mixture. The amount of metals extracted by $0.001 \mathrm{M}$ and $0.01 \mathrm{M}$ OA mixtures was considerably less than the amount extracted by the $0.1 \mathrm{M}$ OA mixture. The percentages of the total soluble metals that entered into the solution phase in the first 15 minutes, however, were essentially identical for $0.001,0.01$, and 0.1 M OA mixtures (Table 9).

A variety of chemical reactions occur in soils and reactions often take place simultaneously. Reaction time may vary from millisecond scale for ion exchange reactions to days (or months or years) for sorption/desorption reactions to reach equilibrium [60]. Metals present in BSL-treated soils may be present in different forms and therefore dissolve at different rates [61]. In the rhizosphere, the biosolids-borne metals are mainly present in solid forms and are not readily available to the growing plants. The dissolution by the root exudates is a significant pathway through which the plant absorbs metals from biosolid-treated soils. We hypothesized that the phytoavailable metals in biosolid-treated soils can be determined by amount of metals dissolved by root exudate derived organic acids in the rhizosphere. The metal update by plants is determined by the kinetics of metal released into solution by organic acids. In this manner, the phytoavailability of biosolid-borne metals may be defined in terms of capacity factor (i.e., organic acids extractable metals in soils), which describes the plant available metal concentration in 

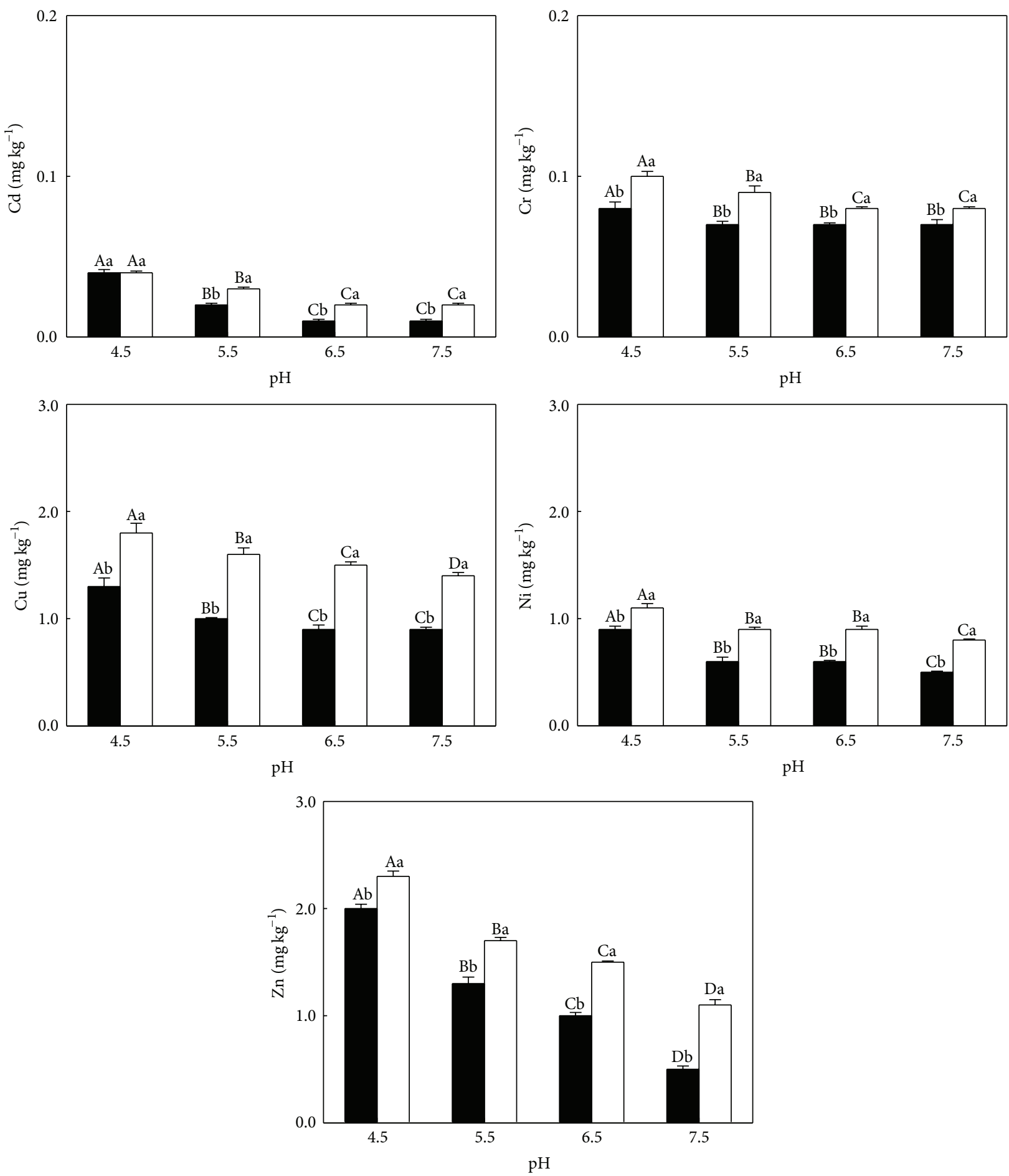

$13.5 \mathrm{mMCa}\left(\mathrm{NO}_{3}\right)_{2}$

ए $0.01 \mathrm{M} \mathrm{OA}$ mixture

Figure 2: Effects of $\mathrm{pH}$ on the extraction of metals (four replicates) in biosolid-treated Romona soil $\left(135 \mathrm{Mgha}^{-1}\right)$ by $13.5 \mathrm{mM} \mathrm{Ca}\left(\mathrm{NO}_{3}\right)_{2}$ electrolyte solution and $0.01 \mathrm{M}$ organic acid mixtures. The differences of metal concentrations among the $\mathrm{pH}$ values were tested by one-way ANOVA. Values followed by the same uppercase letter were not significantly different at $P<0.05$. The differences of the metal concentrations between $13.5 \mathrm{mM} \mathrm{Ca}\left(\mathrm{NO}_{3}\right)_{2}$ and $0.01 \mathrm{M} \mathrm{OA}$ mixture were tested by Student-Newman-Keuls test. Values followed by the same lowercase letter were not significantly different at $P<0.05$. 
TABLE 6: Metals release kinetics of biosolid-treated Romona soil $\left(1,080 \mathrm{Mg} \mathrm{ha}^{-1}\right)$ in different concentrations of organic acid (OA) mixtures.

\begin{tabular}{|c|c|c|c|c|c|c|c|c|c|}
\hline \multirow{2}{*}{ Element } & \multirow{2}{*}{ OA concentration } & \multicolumn{8}{|c|}{ Metal concentration $\left(\mathrm{mg} \mathrm{kg}^{-1}\right)$} \\
\hline & & $15 \mathrm{~min}$ & $30 \mathrm{~min}$ & $1 \mathrm{hr}$ & $2 \mathrm{hrs}$ & $4 \mathrm{hrs}$ & $8 \mathrm{hrs}$ & $24 \mathrm{hrs}$ & $48 \mathrm{hrs}$ \\
\hline \multirow{3}{*}{$\mathrm{Cd}$} & $0.001 \mathrm{M}$ & 0.31 & 0.32 & 0.33 & 0.35 & 0.37 & 0.40 & 0.46 & 0.47 \\
\hline & $0.01 \mathrm{M}$ & 1.16 & 1.21 & 1.24 & 1.28 & 1.35 & 1.49 & 1.73 & 1.75 \\
\hline & $0.1 \mathrm{M}$ & 1.67 & 1.70 & 1.75 & 1.82 & 1.90 & 2.03 & 2.40 & 2.48 \\
\hline \multirow{3}{*}{$\mathrm{Cr}$} & $0.001 \mathrm{M}$ & 0.34 & 0.40 & 0.44 & 0.49 & 0.57 & 0.73 & 1.09 & 1.12 \\
\hline & $0.01 \mathrm{M}$ & 0.85 & 0.95 & 1.03 & 1.16 & 1.39 & 1.67 & 2.49 & 2.57 \\
\hline & $0.1 \mathrm{M}$ & 1.46 & 1.78 & 1.91 & 2.17 & 2.53 & 3.17 & 4.79 & 5.04 \\
\hline \multirow{3}{*}{$\mathrm{Cu}$} & $0.001 \mathrm{M}$ & 2.41 & 2.48 & 2.63 & 2.78 & 2.88 & 3.14 & 3.81 & 3.89 \\
\hline & $0.01 \mathrm{M}$ & 10.7 & 11.1 & 11.7 & 12.1 & 12.8 & 13.8 & 16.8 & 17.5 \\
\hline & $0.1 \mathrm{M}$ & 20.3 & 21.2 & 22.5 & 23.7 & 25.2 & 26.4 & 32.1 & 33.4 \\
\hline \multirow{3}{*}{$\mathrm{Ni}$} & $0.001 \mathrm{M}$ & 2.53 & 2.64 & 2.83 & 2.94 & 3.13 & 3.28 & 3.72 & 3.79 \\
\hline & $0.01 \mathrm{M}$ & 9.80 & 10.2 & 10.9 & 11.4 & 12.1 & 12.5 & 14.5 & 14.8 \\
\hline & $0.1 \mathrm{M}$ & 16.1 & 16.8 & 18.0 & 18.8 & 19.5 & 20.8 & 23.3 & 24.1 \\
\hline \multirow{3}{*}{$\mathrm{Pb}$} & $0.001 \mathrm{M}$ & 0.13 & 0.14 & 0.15 & 0.18 & 0.22 & 0.29 & 0.42 & 0.46 \\
\hline & $0.01 \mathrm{M}$ & 0.34 & 0.36 & 0.38 & 0.45 & 0.54 & 0.67 & 0.99 & 1.03 \\
\hline & $0.1 \mathrm{M}$ & 0.77 & 0.82 & 0.87 & 1.02 & 1.09 & 1.89 & 2.01 & 2.33 \\
\hline \multirow{3}{*}{$\mathrm{Zn}$} & $0.001 \mathrm{M}$ & 25 & 26 & 28 & 29 & 31 & 32 & 36 & 38 \\
\hline & $0.01 \mathrm{M}$ & 104 & 108 & 111 & 115 & 123 & 129 & 145 & 148 \\
\hline & $0.1 \mathrm{M}$ & 205 & 211 & 220 & 227 & 235 & 245 & 275 & 282 \\
\hline
\end{tabular}

TABLE 7: Metals release kinetics of biosolid-treated Romona soil (135 $\left.\mathrm{Mg} \mathrm{ha}^{-1}\right)$ in different concentrations of organic acid (OA) mixtures.

\begin{tabular}{|c|c|c|c|c|c|c|c|c|c|}
\hline \multirow{2}{*}{ Element } & \multirow{2}{*}{ OA concentration } & \multicolumn{8}{|c|}{ Metal concentration $\left(\mathrm{mg} \mathrm{kg}^{-1}\right)$} \\
\hline & & $15 \mathrm{~min}$ & $30 \mathrm{~min}$ & $1 \mathrm{hr}$ & $2 \mathrm{hrs}$ & $4 \mathrm{hrs}$ & $8 \mathrm{hrs}$ & $24 \mathrm{hrs}$ & $48 \mathrm{hrs}$ \\
\hline \multirow{3}{*}{$\mathrm{Cd}$} & $0.001 \mathrm{M}$ & 0.055 & 0.059 & 0.063 & 0.066 & 0.068 & 0.073 & 0.089 & 0.091 \\
\hline & $0.01 \mathrm{M}$ & 0.18 & 0.19 & 0.20 & 0.21 & 0.23 & 0.25 & 0.29 & 0.30 \\
\hline & $0.1 \mathrm{M}$ & 0.79 & 0.83 & 0.88 & 0.92 & 1.01 & 1.10 & 1.26 & 1.29 \\
\hline \multirow{3}{*}{$\mathrm{Cr}$} & $0.001 \mathrm{M}$ & 0.07 & 0.08 & 0.09 & 0.10 & 0.13 & 0.16 & 0.22 & 0.23 \\
\hline & $0.01 \mathrm{M}$ & 0.23 & 0.27 & 0.30 & 0.34 & 0.38 & 0.46 & 0.69 & 0.71 \\
\hline & $0.1 \mathrm{M}$ & 0.91 & 1.07 & 1.13 & 1.23 & 1.47 & 1.80 & 2.63 & 2.68 \\
\hline \multirow{3}{*}{$\mathrm{Cu}$} & $0.001 \mathrm{M}$ & 0.86 & 0.88 & 0.92 & 0.97 & 1.05 & 1.15 & 1.38 & 1.42 \\
\hline & $0.01 \mathrm{M}$ & 2.21 & 2.35 & 2.49 & 2.63 & 2.80 & 2.93 & 3.59 & 3.66 \\
\hline & $0.1 \mathrm{M}$ & 7.6 & 7.8 & 8.3 & 8.9 & 9.4 & 10.1 & 12.6 & 12.7 \\
\hline \multirow{3}{*}{$\mathrm{Ni}$} & $0.001 \mathrm{M}$ & 0.53 & 0.55 & 0.59 & 0.62 & 0.66 & 0.68 & 0.79 & 0.81 \\
\hline & $0.01 \mathrm{M}$ & 1.57 & 1.67 & 1.80 & 1.93 & 2.01 & 2.13 & 2.52 & 2.57 \\
\hline & $0.1 \mathrm{M}$ & 6.8 & 7.3 & 7.8 & 8.4 & 8.9 & 9.5 & 11.0 & 11.3 \\
\hline \multirow{3}{*}{$\mathrm{Pb}$} & $0.001 \mathrm{M}$ & 0.021 & 0.023 & 0.025 & 0.030 & 0.035 & 0.044 & 0.063 & 0.065 \\
\hline & $0.01 \mathrm{M}$ & 0.06 & 0.07 & 0.08 & 0.09 & 0.11 & 0.13 & 0.19 & 0.20 \\
\hline & $0.1 \mathrm{M}$ & 0.32 & 0.34 & 0.38 & 0.45 & 0.53 & 0.62 & 0.90 & 0.94 \\
\hline \multirow{3}{*}{$\mathrm{Zn}$} & $0.001 \mathrm{M}$ & 3.96 & 4.19 & 4.35 & 4.48 & 4.69 & 4.91 & 5.60 & 5.66 \\
\hline & $0.01 \mathrm{M}$ & 21.4 & 22.6 & 23.3 & 24.8 & 25.7 & 27.1 & 30.7 & 31.0 \\
\hline & $0.1 \mathrm{M}$ & 100 & 103 & 108 & 114 & 117 & 121 & 134 & 137 \\
\hline
\end{tabular}

biosolid-treated soil and intensity factor (i.e., the rate at which metals may be dissolved by organic acids), which indicates the rate at which metals will be absorbed by plants. The data presented in Tables 6-8 and Figure 3 may fit the two-site bicontinuum model. Under this conception, there appeared to be two dissolution reactions, a fast reaction, which quickly solubilized this component of the metals, followed by a slow reaction of the remaining components that may continue for a long period of time. These two reactions may occur in series or in parallel. Location and chemical bonding of metals in soil and solution versus metal ratio might be the effects for two pools of metal [62]. The rapid release of metals in the first 15 minutes was fitted into a zero-order kinetics model that

$$
C_{t}=k_{0} \times t \quad \text { for } t=0 \text { to } t=0.25 \text {, }
$$


TABLE 8: Metals release kinetics of control Romona soil in different concentrations of organic acid (OA) mixtures.

\begin{tabular}{|c|c|c|c|c|c|c|c|c|c|}
\hline \multirow{2}{*}{ Element } & \multirow{2}{*}{ OA concentration } & \multicolumn{8}{|c|}{ Metal concentration $\left(\mathrm{mg} \mathrm{kg}^{-1}\right)$} \\
\hline & & $15 \mathrm{~min}$ & $30 \mathrm{~min}$ & $1 \mathrm{hr}$ & $2 \mathrm{hrs}$ & 4 hrs & $8 \mathrm{hrs}$ & $24 \mathrm{hrs}$ & $48 \mathrm{hrs}$ \\
\hline \multirow{3}{*}{$\mathrm{Cd}$} & $0.001 \mathrm{M}$ & 0.0013 & 0.0014 & 0.0015 & 0.0015 & 0.0016 & 0.0017 & 0.002 & 0.002 \\
\hline & $0.01 \mathrm{M}$ & 0.0084 & 0.0088 & 0.0091 & 0.0097 & 0.0102 & 0.0115 & 0.0137 & 0.014 \\
\hline & $0.1 \mathrm{M}$ & 0.020 & 0.021 & 0.022 & 0.023 & 0.025 & 0.027 & 0.031 & 0.032 \\
\hline \multirow{3}{*}{$\mathrm{Cr}$} & $0.001 \mathrm{M}$ & 0.010 & 0.012 & 0.013 & 0.016 & 0.019 & 0.023 & 0.034 & 0.035 \\
\hline & $0.01 \mathrm{M}$ & 0.015 & 0.018 & 0.020 & 0.023 & 0.028 & 0.035 & 0.052 & 0.053 \\
\hline & $0.1 \mathrm{M}$ & 0.11 & 0.13 & 0.14 & 0.16 & 0.20 & 0.23 & 0.35 & 0.36 \\
\hline \multirow{3}{*}{$\mathrm{Cu}$} & $0.001 \mathrm{M}$ & 0.1071 & 0.1139 & 0.1207 & 0.1275 & 0.1343 & 0.1433 & 0.170 & 0.177 \\
\hline & $0.01 \mathrm{M}$ & 0.35 & 0.36 & 0.39 & 0.41 & 0.44 & 0.47 & 0.56 & 0.58 \\
\hline & $0.1 \mathrm{M}$ & 1.97 & 2.03 & 2.12 & 2.21 & 2.34 & 2.51 & 3.11 & 3.17 \\
\hline \multirow{3}{*}{$\mathrm{Ni}$} & $0.001 \mathrm{M}$ & 0.0603 & 0.063 & 0.0675 & 0.0702 & 0.0737 & 0.0773 & 0.0891 & 0.090 \\
\hline & $0.01 \mathrm{M}$ & 0.39 & 0.42 & 0.47 & 0.48 & 0.51 & 0.53 & 0.63 & 0.64 \\
\hline & $0.1 \mathrm{M}$ & 1.07 & 1.12 & 1.18 & 1.24 & 1.33 & 1.42 & 1.64 & 1.67 \\
\hline \multirow{3}{*}{$\mathrm{Pb}$} & $0.001 \mathrm{M}$ & n.d. $^{\dagger}$ & n.d. $^{\dagger}$ & n.d. $^{\dagger}$ & n.d. $^{\dagger}$ & n.d. $^{\dagger}$ & n.d. $^{\dagger}$ & n.d. $^{\dagger}$ & n.d. ${ }^{\dagger}$ \\
\hline & $0.01 \mathrm{M}$ & n.d. ${ }^{\dagger}$ & n.d. ${ }^{\dagger}$ & n.d. ${ }^{\dagger}$ & n.d. ${ }^{\dagger}$ & n.d. ${ }^{\dagger}$ & n.d. ${ }^{\dagger}$ & n.d. $^{\dagger}$ & n.d. ${ }^{\dagger}$ \\
\hline & $0.1 \mathrm{M}$ & 0.014 & 0.016 & 0.017 & 0.019 & 0.024 & 0.030 & 0.042 & 0.044 \\
\hline \multirow{3}{*}{$\mathrm{Zn}$} & $0.001 \mathrm{M}$ & 0.30 & 0.32 & 0.34 & 0.35 & 0.37 & 0.38 & 0.44 & 0.45 \\
\hline & $0.01 \mathrm{M}$ & 1.95 & 2.06 & 2.17 & 2.26 & 2.34 & 2.44 & 2.77 & 2.79 \\
\hline & $0.1 \mathrm{M}$ & 5.3 & 5.6 & 6.0 & 6.2 & 6.5 & 6.8 & 7.8 & 7.9 \\
\hline
\end{tabular}

${ }^{\dagger}$ Concentration was below detection limits of the AAS for $\mathrm{Pb}=0.001 \mathrm{mg} \mathrm{kg}^{-1}$.

where $C_{t}\left(\mathrm{mg} \mathrm{kg}^{-1}\right)$ is the metal concentration at time $t$ (hour) and $k_{0}\left(\mathrm{mg} \mathrm{kg}^{-1} \mathrm{hr}^{-1}\right)$ is the zero-order kinetics constant. The remainder portion of the metal dissolution reaction follows a first-order kinetics model that

$$
C_{t}=\left(0.25 \times k_{0}\right)+\left\{C_{s} \times\left[1-e^{-k_{1} \times(t-0.25)}\right]\right\} ; \quad \text { for } t>0.25,
$$

where $C_{s}$ represents the ultimate metal release due to the first-order dissolution reaction $\left(\mathrm{mg} \mathrm{kg}^{-1}\right)$ and $k_{1}$ is the firstorder kinetics constant $\left(\mathrm{hr}^{-1}\right)$. The kinetics models depicting the metal dissolution reactions are summarized in Table 10. The concentrations of OA mixtures and the amount of BSLborne metals in the soils determined the metals' dissolution and their availability to plants. For the first-order slow metal release, the rate constants for a metal $\left(k_{1}\right)$ did not vary significantly. $k_{1}$ ranged from 0.07 to $0.13,0.08$ to $0.09,0.07$ to $0.09,0.12$ to $0.14,0.08$ to 0.09 , and 0.1 to 0.13 for $\mathrm{Cd}, \mathrm{Cr}$, $\mathrm{Cu}, \mathrm{Ni}, \mathrm{Pb}$, and $\mathrm{Zn}$, respectively.

For the zero-order rapid metal release, the metal dissolution of the soil increased with the concentration of OA mixtures and the amount of metals dissolved by the $\mathrm{OA}$ mixture of a given concentration increased with the amount of BSL-borne metals in the soils. When the concentrations of OA mixtures varied from 0.001 to $0.1 \mathrm{M}, k_{0}$ for a given soil generally increased by 5 to 10 times. At the same OA mixture concentration, $k_{0}$ of metals varied by $20-100,15-60$, and 10-60 times for control, soil receiving $135 \mathrm{Mg} \mathrm{ha}^{-1}$, and soil receiving $1,080 \mathrm{Mg} \mathrm{ha}^{-1}$ of BSL, respectively.

The total metals that were extractable by the OA mixtures were calculated as the sum of metal rapidly released by the zero-order reaction $\left(0.25 \times k_{0}\right)$ and the metal slowly released through the subsequent first-order reaction $\left(C_{s}\right)$. The total
OA extractable metals would indicate the amount of metals possibly available to plants. The amount of metals that were extractable from BSL-treated soil $\left(1,080 \mathrm{Mgha}^{-1}\right)$ by $0.1 \mathrm{M}$ OA mixture is presented in Table 11.

Under this metal release model, plants grown on BSLtreated soils would be expected to absorb metals from the rapid release pool first. As the metal release followed a zero-order reaction, one would expect the plant uptake, and therefore tissue concentration, of metals to remain essentially the same until metals in this pool are exhausted, at which time the plant uptake of metals, and therefore the tissue concentration, is expected to decrease as metals in the slow release pool would be available to plants at a much slower rate.

The data presented in Tables 6-8 and Figure 3 also may fit the first-order kinetics model. Under this conception, the slope of the curve approached 0 as the time increased (Table 12). The trend on the cumulative metal extracted with respect to time was fitted into a first-order kinetics model and can be expressed as

$$
C_{t}=C_{0} \times\left(1-e^{-k_{1} \times t}\right),
$$

where $C_{t}\left(\mathrm{mg} \mathrm{kg}^{-1}\right)$ is the metal concentration at time $t$ (hour) and $k_{1}\left(\mathrm{hr}^{-1}\right)$ is the first-order kinetics constant and $C_{0}$ represents the ultimate metal release due to the first-order dissolution reaction $\left(\mathrm{mg} \mathrm{kg}^{-1}\right)$. The concentrations of $\mathrm{OA}$ mixtures and the amount of BSL-borne metals in the soils determined the metals' dissolution and their availability to plants. For the first-order metal release, the rate constants for a metal $\left(k_{1}\right)$ ranged from 3.88 to $6.25,0.30$ to $0.51,3.81$ to 4.88 , 3.79 to $5.53,0.24$ to 0.50 , and 4.85 to 6.80 for $\mathrm{Cd}, \mathrm{Cr}, \mathrm{Cu}, \mathrm{Ni}$, 

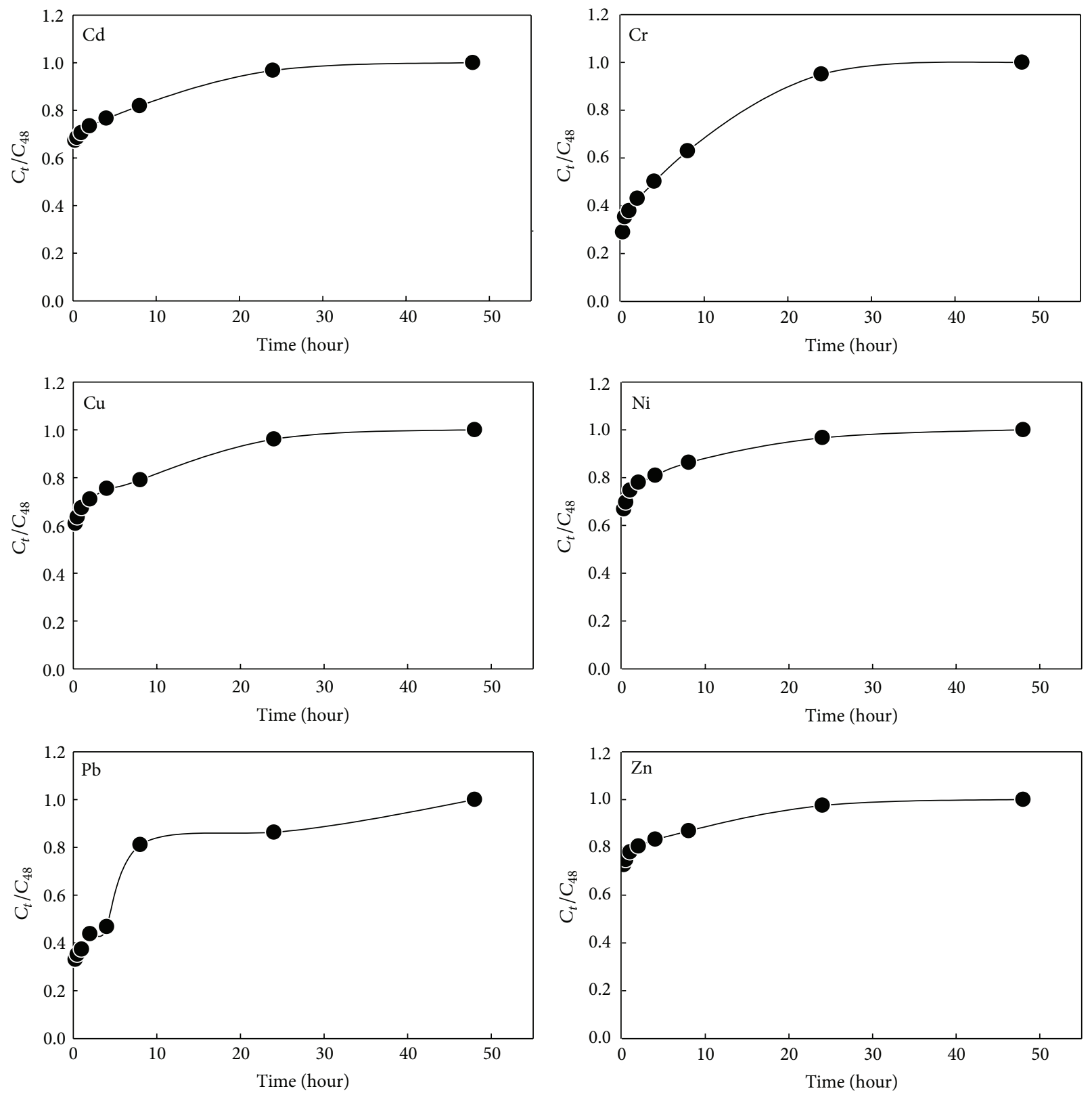

Figure 3: Time-dependent Cd, Cr, Cu, Ni, Pb, and $\mathrm{Zn}$ dissolutions of the biosolid-treated Romona soil $\left(1,080 \mathrm{Mg} \mathrm{ha}^{-1}\right)$ in $0.1 \mathrm{M}$ organic acid mixtures $\left(C_{t}\right.$ denotes concentration at time $t$ and $C_{48}$ denotes concentration at 48 hours).

$\mathrm{Pb}$, and $\mathrm{Zn}$, respectively (Table 13$)$. The total metals $\left(C_{0}\right)$ that were extractable by the $\mathrm{OA}$ mixtures were the same as the total released amounts in Table 11. The total OA extractable metals would indicate the amount of metals possibly available to plants.

\section{Conclusion}

(1) Metals present in BSL-treated soils are more extractable by an OA mixture than indigenous metals of the soil. In BSL-treated soil, more than $90 \%$ of metals extracted may be attributed to BSL-borne metals.
(2) In general, the amount of metals extracted decreased with the increase of the $\mathrm{pH}$, and at the same (4.8) $\mathrm{pH}$ level, the OA mixture extracted more metals than the $13.5 \mathrm{mM} \mathrm{Ca}\left(\mathrm{NO}_{3}\right)_{2}$ electrolyte solution.

(3) In general, $\mathrm{Cd}, \mathrm{Cu}, \mathrm{Ni}$, and $\mathrm{Zn}$ were more readily extractable by the OA mixtures and readily absorbed by plants grown on BSL-treated soils than $\mathrm{Cr}$ and $\mathrm{Pb}$.

(4) The amount of metals extracted was a function of concentration of OA mixtures. Higher concentrations of OA mixture resulted in greater extraction of metals from the BSL-treated soils. 
TABLE 9: Metals of control and biosolid-treated soils solubilized by organic acid (OA) mixtures in the first 15 minutes of equilibration.

\begin{tabular}{|c|c|c|c|c|c|c|c|}
\hline \multirow[t]{2}{*}{ Biosolid treatment ${ }^{\dagger}$} & \multirow[t]{2}{*}{ Concentration of OA mixtures } & \multicolumn{6}{|c|}{$\begin{array}{l}\text { Metals dissolved in } 15 \text { minutes } \\
\text { (\% of total dissolved) }\end{array}$} \\
\hline & & $\mathrm{Cd}$ & $\mathrm{Cr}$ & $\mathrm{Cu}$ & $\mathrm{Ni}$ & $\mathrm{Pb}$ & $\mathrm{Zn}$ \\
\hline \multirow{3}{*}{ Control } & $0.001 \mathrm{M}$ & 63 & 29 & 61 & 67 & n.d. . $^{\prime}$ & 67 \\
\hline & $0.01 \mathrm{M}$ & 60 & 28 & 60 & 61 & n.d. ${ }^{\ddagger}$ & 70 \\
\hline & $0.1 \mathrm{M}$ & 63 & 31 & 62 & 64 & 32 & 67 \\
\hline \multirow{3}{*}{$135 \mathrm{Mg} \mathrm{ha}^{-1}$} & $0.001 \mathrm{M}$ & 60 & 30 & 61 & 66 & 32 & 70 \\
\hline & $0.01 \mathrm{M}$ & 60 & 32 & 60 & 61 & 30 & 69 \\
\hline & $0.1 \mathrm{M}$ & 62 & 34 & 60 & 60 & 34 & 73 \\
\hline \multirow{3}{*}{ 1,080 $\mathrm{Mg} \mathrm{ha}^{-1}$} & $0.001 \mathrm{M}$ & 66 & 30 & 62 & 67 & 28 & 66 \\
\hline & $0.01 \mathrm{M}$ & 66 & 33 & 61 & 66 & 33 & 70 \\
\hline & $0.1 \mathrm{M}$ & 67 & 29 & 61 & 67 & 33 & 73 \\
\hline
\end{tabular}

${ }^{\dagger}$ Obtained at Moreno Field Station of the University of California, Riverside, CA. From 1976 through 1981, composted biosolids were applied at dry weight rates of 0 (control), 22.5, and $180 \mathrm{Mg} \mathrm{ha}^{-1} \mathrm{yr}^{-1}$, respectively.

${ }^{\ddagger}$ Concentration was below detection limits of the AAS for $\mathrm{Pb}=0.001 \mathrm{mg} \mathrm{kg}^{-1}$.

TABLE 10: Kinetics constant for metal dissolution reaction extracted by organic acid (OA) mixtures according to (1) and (2) ${ }^{\dagger}$.

\begin{tabular}{|c|c|c|c|c|c|c|c|c|c|c|c|c|c|}
\hline \multirow{3}{*}{$\begin{array}{l}\text { Biosolid treatment } \\
\left(\mathrm{Mg} \mathrm{ha}^{-1}\right)\end{array}$} & \multirow{3}{*}{ Metal extracted by OAs } & \multicolumn{12}{|c|}{ Zero- and first-order kinetics constant } \\
\hline & & \multicolumn{2}{|c|}{$\mathrm{Cd}$} & \multicolumn{2}{|c|}{$\mathrm{Cr}$} & \multicolumn{2}{|c|}{$\mathrm{Cu}$} & \multicolumn{2}{|c|}{$\mathrm{Ni}$} & \multicolumn{2}{|c|}{$\mathrm{Pb}$} & \multicolumn{2}{|c|}{$\mathrm{Zn}$} \\
\hline & & $k_{0}$ & $k_{1}$ & $k_{0}$ & $k_{1}$ & $k_{0}$ & $k_{1}$ & $k_{0}$ & $k_{1}$ & $k_{0}$ & $k_{1}$ & $k_{0}$ & $k_{1}$ \\
\hline \multirow{3}{*}{ Control } & $0.001 \mathrm{M}$ & 0.01 & $0.11^{\mathrm{a}}$ & 0.04 & 0.09 & 0.43 & 0.09 & 0.24 & 0.12 & n.d. ${ }^{\S}$ & n.d. ${ }^{\S}$ & 1.2 & 0.12 \\
\hline & $0.01 \mathrm{M}$ & 0.03 & $0.10^{\mathrm{a}}$ & 0.06 & 0.09 & 1.40 & 0.09 & 1.56 & 0.14 & n.d. ${ }^{\S}$ & n.d. ${ }^{\S}$ & 7.8 & 0.13 \\
\hline & $0.1 \mathrm{M}$ & 0.08 & $0.12^{\mathrm{a}}$ & 0.44 & 0.08 & 7.88 & 0.07 & 4.28 & 0.12 & 0.06 & 0.09 & 21.2 & 0.13 \\
\hline \multirow{3}{*}{135} & $0.001 \mathrm{M}$ & 0.22 & $0.09^{\mathrm{a}}$ & 0.28 & 0.09 & 3.44 & 0.09 & 2.12 & 0.12 & 0.84 & 0.09 & 15.8 & 0.11 \\
\hline & $0.01 \mathrm{M}$ & 0.72 & $0.12^{\mathrm{a}}$ & 0.92 & 0.08 & 8.84 & 0.09 & 6.28 & 0.12 & 0.24 & 0.09 & 85.6 & 0.13 \\
\hline & $0.1 \mathrm{M}$ & 3.16 & $0.13^{\mathrm{a}}$ & 3.64 & 0.09 & 30.4 & 0.08 & 26.8 & 0.14 & 1.28 & 0.08 & 400 & 0.13 \\
\hline \multirow{3}{*}{1,080} & $0.001 \mathrm{M}$ & 1.24 & $0.10^{\mathrm{a}}$ & 1.36 & 0.09 & 9.64 & 0.08 & 10.1 & 0.14 & 0.52 & 0.08 & 100 & 0.12 \\
\hline & $0.01 \mathrm{M}$ & 4.64 & $0.10^{\mathrm{a}}$ & 3.40 & 0.08 & 42.8 & 0.07 & 39.2 & 0.12 & 1.36 & 0.08 & 416 & 0.12 \\
\hline & $0.1 \mathrm{M}$ & 6.68 & $0.07^{\mathrm{a}}$ & 5.84 & 0.08 & 81.2 & 0.08 & 64.4 & 0.12 & 3.08 & 0.08 & 820 & 0.10 \\
\hline
\end{tabular}

${ }^{\dagger}$ Values represent means of two replicates. The differences of first-order kinetics constant for Cd among the treatments were tested by one-way ANOVA. In each column, values followed by the same lowercase letter were not significantly different at $P<0.05$.

${ }^{\ddagger}$ Obtained at Moreno Field Station of the University of California, Riverside, CA. From 1976 through 1981, composted biosolids were applied at dry weight rates of 0 (control), 22.5, and $180 \mathrm{Mg} \mathrm{ha}^{-1} \mathrm{yr}^{-1}$, respectively.

${ }^{\S}$ Concentration was below detection limits of the AAS for $\mathrm{Pb}=0.001 \mathrm{mg} \mathrm{kg}^{-1}$.

TABLE 11: Amounts of metals that were extractable from the biosolidtreated Romona soil $\left(1,080 \mathrm{Mg} \mathrm{ha}^{-1}\right)$ by $0.1 \mathrm{M}$ organic acid mixture.

\begin{tabular}{lccc}
\hline Element & $\begin{array}{c}\text { Rapid release } \\
\left(\mathrm{mg} \mathrm{kg}^{-1}\right)\end{array}$ & $\begin{array}{c}\text { Slow release } \\
\left(\mathrm{mg} \mathrm{kg}^{-1}\right)\end{array}$ & $\begin{array}{c}\text { Total release } \\
\left(\mathrm{mg} \mathrm{kg}^{-1}\right)\end{array}$ \\
\hline $\mathrm{Cd}$ & 1.67 & 0.86 & 2.53 \\
$\mathrm{Cr}$ & 1.46 & 3.74 & 5.20 \\
$\mathrm{Cu}$ & 20.3 & 13.7 & 34.0 \\
$\mathrm{Ni}$ & 16.1 & 8.60 & 24.7 \\
$\mathrm{~Pb}$ & 0.77 & 1.73 & 2.50 \\
$\mathrm{Zn}$ & 205 & 80.0 & 285 \\
\hline
\end{tabular}

(5) The percentages of total BSL-borne metals extracted were $13.8,1.63,7.95,14.1,1.03$, and $24.2 \%$ for $\mathrm{Cd}$, $\mathrm{Cr}, \mathrm{Cu}, \mathrm{Ni}, \mathrm{Pb}$, and $\mathrm{Zn}$, respectively. If OAs were responsible for converting metals in solid phases
TABLE 12: The slope ${ }^{\dagger}$ of metal extracted from the biosolid-treated Romona soil $\left(1,080 \mathrm{Mg} \mathrm{ha}^{-1}\right)$ by $0.1 \mathrm{M}$ organic acid mixtures according to (3).

\begin{tabular}{lcccccccc}
\hline Element & $k_{1}$ & $k_{2}$ & $k_{3}$ & $k_{4}$ & $k_{5}$ & $k_{6}$ & $k_{7}$ & $k_{8}$ \\
\hline $\mathrm{Cd}$ & 6.68 & 3.40 & 1.75 & 0.91 & 0.48 & 0.25 & 0.10 & 0.05 \\
$\mathrm{Cr}$ & 5.84 & 3.56 & 1.91 & 1.09 & 0.63 & 0.40 & 0.20 & 0.11 \\
$\mathrm{Cu}$ & 81.2 & 42.4 & 22.5 & 11.9 & 6.30 & 3.30 & 1.34 & 0.70 \\
$\mathrm{Ni}$ & 64.4 & 33.6 & 18.0 & 9.40 & 4.88 & 2.60 & 0.97 & 0.50 \\
$\mathrm{~Pb}$ & 3.08 & 1.64 & 0.87 & 0.51 & 0.27 & 0.24 & 0.08 & 0.05 \\
$\mathrm{Zn}$ & 820 & 422 & 220 & 113 & 58.8 & 30.6 & 11.5 & 5.88 \\
\hline
\end{tabular}

${ }^{\dagger}$ Values of $k_{1}, k_{2}, k_{3}, k_{4}, k_{5}, k_{6}, k_{7}$ or $k_{8}$ indicate the slopes of metal extracted at $15 \mathrm{~min} ., 30 \mathrm{~min} ., 1 \mathrm{hr}, 2$ hrs., 4 hrs., 8 hrs., 24 hrs., and 48 hrs.

into plant available forms, the amount and rate of metals' solubilization would be indicative of metals' availability to plants. 
TABLE 13: First-order kinetics constant for metal dissolution reaction extracted by organic acid (OA) mixtures according to (3).

\begin{tabular}{|c|c|c|c|c|c|c|c|}
\hline \multirow{2}{*}{ Biosolid treatment $^{\dagger}$} & \multirow{2}{*}{ Metal extracted by OAs } & \multicolumn{6}{|c|}{ First-order kinetics constant $\left(k_{1}\right)$} \\
\hline & & $\mathrm{Cd}$ & $\mathrm{Cr}$ & $\mathrm{Cu}$ & $\mathrm{Ni}$ & $\mathrm{Pb}$ & $\mathrm{Zn}$ \\
\hline \multirow{3}{*}{ Control } & $0.001 \mathrm{M}$ & 4.71 & 0.34 & 4.11 & 4.87 & n.d. ${ }^{\ddagger}$ & 5.00 \\
\hline & $0.01 \mathrm{M}$ & 3.99 & 0.30 & 3.90 & 3.93 & n.d. ${ }^{\ddagger}$ & 5.42 \\
\hline & $0.1 \mathrm{M}$ & 4.30 & 0.37 & 4.49 & 4.46 & 0.36 & 4.92 \\
\hline \multirow{3}{*}{$135 \mathrm{Mg} \mathrm{ha}^{-1}$} & $0.001 \mathrm{M}$ & 4.13 & 0.38 & 4.05 & 4.65 & 0.38 & 5.63 \\
\hline & $0.01 \mathrm{M}$ & 3.88 & 0.51 & 4.03 & 3.95 & 0.40 & 5.33 \\
\hline & $0.1 \mathrm{M}$ & 3.96 & 0.48 & 3.81 & 3.79 & 0.50 & 6.06 \\
\hline \multirow{3}{*}{$1,080 \mathrm{Mg} \mathrm{ha}^{-1}$} & $0.001 \mathrm{M}$ & 4.93 & 0.32 & 4.30 & 4.81 & 0.24 & 4.85 \\
\hline & $0.01 \mathrm{M}$ & 5.16 & 0.40 & 4.41 & 4.81 & 0.32 & 5.75 \\
\hline & $0.1 \mathrm{M}$ & 6.25 & 0.37 & 4.88 & 5.53 & 0.43 & 6.80 \\
\hline
\end{tabular}

${ }^{\dagger}$ Obtained at Moreno Field Station of the University of California, Riverside, CA. From 1976 through 1981 composted BSL were applied at dry weight rates of 0 (control), 22.5, and $180 \mathrm{Mg} \mathrm{ha}^{-1} \mathrm{yr}^{-1}$, respectively.

${ }^{\ddagger}$ Concentration was below detection limits of the AAS for $\mathrm{Pb}=0.001 \mathrm{mg} \mathrm{kg}^{-1}$.

(6) A rapid dissolution of metals occurred in the first 15 minutes of mixture. For $\mathrm{Cd}, \mathrm{Cu}, \mathrm{Ni}$, and $\mathrm{Zn}$, approximately $60-70 \%$ of the metals were released. For $\mathrm{Cr}$ and $\mathrm{Pb}$, the initial releases were approximately $30 \%$ of the total.

(7) The data of the metal dissolution kinetics in BSLtreated soils may fit either the two-site bicontinuum model in which significant amounts of the soluble metals were dissolved rapidly, following a zero-order dissolution kinetics and the remaining soluble metals released slowly over a long period of time, following a first-order dissolution kinetics, or first-order dissolution kinetics alone.

\section{Competing Interests}

The authors declare that they have no competing interests.

\section{Acknowledgments}

The authors gratefully acknowledge Mr. D. Thomason, Mr. W. Smith, and Ms. N. J. Krage for technical assistance. This research was supported by the Water Environmental Research Foundation (WERF-97-REM-5) and California Baptist University's Microgrant.

\section{References}

[1] A. H. M. Veeken and H. V. M. Hamelers, "Removal of heavy metals from sewage sludge by extraction with organic acids," Water Science and Technology, vol. 40, no. 1, pp. 129-136, 1999.

[2] D. del Mundo Dacera and S. Babel, "Use of citric acid for heavy metals extraction from contaminated sewage sludge for land application," Water Science and Technology, vol. 54, no. 9, pp. 129-135, 2006.

[3] W. P. Inskeep and S. D. Comfort, "Thermodynamic predictions for the effects of root exudates on metal speciation in the rhizosphere," Journal of Plant Nutrition, vol. 9, no. 3-7, pp. 567$586,1986$.
[4] M. Mench, J. L. Morel, A. Guckert, and B. Guillet, "Metal binding with root exudates of low molecular weight," Journal of Soil Science, vol. 39, no. 4, pp. 521-527, 1988.

[5] G. S. R. Krishnamurti, G. Cieslinski, P. M. Huang, and K. C. J. Van Rees, "Kinetics of cadmium release from soils as influenced by organic acids: implication in cadmium availability," Journal of Environmental Quality, vol. 26, no. 1, pp. 271-277, 1997.

[6] J. Kumpiene, A. Lagerkvist, and C. Maurice, "Stabilization of As, $\mathrm{Cr}, \mathrm{Cu}, \mathrm{Pb}$ and $\mathrm{Zn}$ in soil using amendments-a review," Waste Management, vol. 28, no. 1, pp. 215-225, 2008.

[7] M. C. Hernandez-Soriano and J. C. Jimenez-Lopez, "Effects of soil water content and organic matter addition on the speciation and bioavailability of heavy metals," Science of the Total Environment, vol. 423, pp. 55-61, 2012.

[8] A. C. Chang, A. L. Page, and B.-J. Koo, "Biogeochemistry of phosphorus, iron, and trace elements in soils as influenced by soil-plant microbial interactions," Developments in Soil Science, vol. 28, no. 2, pp. 43-57, 2002.

[9] M. Treeby, H. Marschner, and V. Römheld, "Mobilization of iron and other micronutrient cations from a calcareous soil by plantborne, microbial, and synthetic metal chelators," Plant and Soil, vol. 114, no. 2, pp. 217-226, 1989.

[10] F. Awad and V. Römheld, "Mobilization of heavy metals from a contaminated calcareous soil by plant borne and synthetic chelators and their uptake by wheat plants," Journal of Plant Nutrition, vol. 23, no. 11-12, pp. 1847-1855, 2000.

[11] B.-J. Koo, A. C. Chang, A. L. Page, D. E. Crowley, and A. Taylor, "Availability and plant uptake of biosolid-borne metals," Applied and Environmental Soil Science, vol. 2013, Article ID 892036, 10 pages, 2013.

[12] T. Mimmo, M. Ghizzi, C. Marzadori, and C. E. Gessa, "Organic acid extraction from rhizosphere soil: effect of field-moist, dried and frozen samples," Plant and Soil, vol. 312, no. 1-2, pp. 175-184, 2008.

[13] V. Römheld and F. Awad, "Significance of root exudates in acquisition of heavy metals from a contaminated calcareous soil by graminaceous species," Journal of Plant Nutrition, vol. 23, no. 11-12, pp. 1857-1866, 2000.

[14] L. Ström, A. G. Owen, D. L. Godbold, and D. L. Jones, "Organic acid behaviour in a calcareous soil implications for rhizosphere nutrient cycling," Soil Biology and Biochemistry, vol. 37, no. 11, pp. 2046-2054, 2005. 
[15] S. A. Wasay, S. F. Barrington, and S. Tokunaga, "Remediation of soils polluted by heavy metals using salts of organic acids and chelating agents," Environmental Technology, vol. 19, no. 4, pp. 369-379, 1998.

[16] L. Di Palma and R. Mecozzi, "Heavy metals mobilization from harbour sediments using EDTA and citric acid as chelating agents," Journal of Hazardous Materials, vol. 147, no. 3, pp. 768$775,2007$.

[17] A. Piccolo, S. Nardi, and G. Concheri, "Structural characteristics of humic substances as related to nitrate uptake and growth regulation in plant systems," Soil Biology and Biochemistry, vol. 24, no. 4, pp. 373-380, 1992.

[18] S. Nardi, F. Reniero, and G. Concheri, "Soil organic matter mobilization by root exudates of three maize hybrids," Chemosphere, vol. 35, no. 10, pp. 2237-2244, 1997.

[19] B. Dinkelaker, V. Römheld, and H. Marschner, "Citric acid excretion and precipitation of calcium citrate in the rhizosphere of white lupin (Lupinus albus L.)," Plant, Cell and Environment, vol. 12, no. 3, pp. 285-292, 1989.

[20] Z. Rengel and V. Römheld, "Root exudation and Fe uptake and transport in wheat genotypes differing in tolerance to $\mathrm{Zn}$ deficiency," Plant and Soil, vol. 222, no. 1-2, pp. 25-34, 2000.

[21] H. Nietfeld and J. Prenzel, "Modeling the reactive ion dynamics in the rhizosphere of tree roots growing in acid soils. I. Rhizospheric distribution patterns and root uptake of $\mathrm{M}_{b}$ cations as affected by root-induced $\mathrm{pH}$ and $\mathrm{Al}$ dynamics," Ecological Modelling, vol. 307, pp. 48-65, 2015.

[22] A. A. Pohlman and J. G. McColl, "Kinetics of metal dissolution from forest soils by soluble organic acids," Journal of Environmental Quality, vol. 15, no. 1, pp. 86-92, 1986.

[23] D. L. Jones and L. V. Kochian, "Aluminium-organic acid interactions in acid soils: I. Effect of root-derived organic acids on the kinetics of $\mathrm{Al}$ dissolution," Plant and Soil, vol. 182, no. 2, pp. 221-228, 1996.

[24] M. Mench and E. Martin, "Mobilization of cadmium and other metals from two soils by root exudates of Zea mays L., Nicotiana tabacum L. and Nicotiana rustica L.," Plant and Soil, vol. 132, no. 2, pp. 187-196, 1991.

[25] L. Ruiz and J. C. Arvieu, "Measurement of $\mathrm{pH}$ gradients in the rhizosphere," Symbiosis, vol. 9, no. 1-3, pp. 71-75, 1990.

[26] K. Fujii, C. Hayakawa, P. A. W. Van Hees, S. Funakawa, and T. Kosaki, "Biodegradation of low molecular weight organic compounds and their contribution to heterotrophic soil respiration in three Japanese forest soils," Plant and Soil, vol. 334, no. 1, pp. 475-489, 2010.

[27] P. Cambier and G. Sposito, "Interactions of citric acid and synthetic hydroxy-aluminum montmorillonite," Clays and Clay Minerals, vol. 39, no. 2, pp. 158-166, 1991.

[28] R. P. T. Janssen, M. G. M. Bruggenwert, and W. H. Van Riemsdijk, "Interactions between citrate and montmorillonite-Al hydroxide polymer systems," European Journal of Soil Science, vol. 48, no. 3, pp. 463-472, 1997.

[29] J. L. Schroder, H. Zhang, D. Zhou et al., "The effect of long-term annual application of biosolids on soil properties, phosphorus, and metals," Soil Science Society of America Journal, vol. 72, no. 1, pp. 73-82, 2008.

[30] K. Sakurai and P. M. Huang, "Cadmium adsorption on the hydroxyaluminum-montmorillonite complex as influenced by oxalate," in Environmental Impact of Soil Component Interactions: Vol. II, Metals, Other Inorganics, and Microbial Activities, P. M. Huang, J. Berthelin, J.-M. Bollag, W. B. McGill, and A. L.
Page, Eds., pp. 39-46, Lewis Publisher, Boca Raton, Fla, USA, 1995.

[31] S. Taniguchi, N. Yamagata, and K. Sakurai, "Cadmium adsorption on hydroxyl-aluminosilicate-montmorillonite complex as influenced by oxalate and citrate," Soil Science and Plant Nutrition, vol. 46, no. 2, pp. 315-324, 2000.

[32] F. M. Eaton, "Automatically operated sand-culture equipment," Journal of Agricultural Research, vol. 53, pp. 433-444, 1936.

[33] H. Jenny and R. Overstreet, "Contact effects between plant roots and soil colloids," Proceedings of the National Academy of Sciences of the United State of America, vol. 24, no. 9, pp. 384-392, 1938.

[34] B.-J. Koo, A. C. Chang, D. E. Crowley, and A. L. Page, "Characterization of organic acids recovered from rhizosphere of corn grown on biosolids-treated medium," Communications in Soil Science and Plant Analysis, vol. 37, no. 5-6, pp. 871-887, 2006.

[35] L. M. Candalaria, Interactions of citric acid and synthetic hydroxy-aluminum montmorillonite [Ph.D. dissertation], University of California, Riverside, Calif, USA, 1995.

[36] M. Tagliavini, A. Masia, and M. Quartieri, "Bulk soil pH and rhizosphere $\mathrm{pH}$ of peach trees in calcareous and alkaline soils as affected by the form of nitrogen fertilizers," Plant and Soil, vol. 176, no. 2, pp. 263-271, 1995.

[37] W. D. C. Schenkeveld and S. M. Kraemer, "Equilibrium and kinetic modelling of the dynamic rhizosphere," Plant and Soil, vol. 386, no. 1, pp. 395-397, 2015.

[38] P. H. Nye, "Changes of $\mathrm{pH}$ across the rhizosphere induced by roots," Plant and Soil, vol. 61, no. 1-2, pp. 7-26, 1981.

[39] H. Marschner, V. Romheld, and M. Kissel, "Different strategies in higher plants in mobilization and uptake of iron," Journal of Plant Nutrition, vol. 9, no. 3, pp. 695-713, 1986.

[40] T. S. Gahoonia, "Influence of root-induced pH on the solubility of soil aluminium in the rhizosphere," Plant and Soil, vol. 149, no. 2, pp. 289-291, 1993.

[41] H. Marschner, V. Römheld, and I. Cakmak, "Root-induced changes of nutrient availability in the rhizosphere," Journal of Plant Nutrition, vol. 10, no. 9, pp. 1175-1184, 1987.

[42] R. A. Youssef and M. Chino, "Root-induced changes in the rhizosphere of plants: I. pH changes in relation to the bulk soil," Soil Science and Plant Nutrition, vol. 35, no. 3, pp. 461-468, 1989.

[43] H. Marschner and V. Römheld, "In vivo measurement of rootinduced $\mathrm{pH}$ changes at the soil-root interface: effect of plant species and nitrogen source," Zeitschrift für Pflanzenphysiologie, vol. 111, no. 3, pp. 241-251, 1983.

[44] P. R. Darrah, "The rhizosphere and plant nutrition: a quantitative approach," Plant and Soil, vol. 155-156, no. 1, pp. 1-20, 1993.

[45] H. T. Gollany and T. E. Schumacher, "Combined use of colorimetric and microelectrode methods for evaluating rhizosphere pH," Plant and Soil, vol. 154, no. 2, pp. 151-159, 1993.

[46] H.-N. Hyun, A. C. Chang, D. R. Parker, and A. L. Page, "Cadmium solubility and phytoavailability in sludge-treated soil: effects of soil organic carbon," Journal of Environmental Quality, vol. 27, no. 2, pp. 329-334, 1998.

[47] C. G. Millward and P. D. Kluckner, "Microwave digestion technique for the extraction of minerals from environmental marine sediments for analysis by inductively coupled plasma atomic emission spectrometry and atomic absorption spectrometry," Journal of Analytical Atomic Spectrometry, vol. 4, no. 8, pp. 709713, 1989.

[48] W. R. Fischer, H. Flessa, and G. Schaller, "pH values and redox potentials in microsites of the rhizosphere," Zeitschrift für 
Pflanzenernährung und Bodenkunde, vol. 152, no. 2, pp. 191-195, 1989.

[49] P. Hinsinger and R. J. Gilkes, "Mobilization of phosphate from phosphate rock and alumina-sorbed phosphate by the roots of ryegrass and clover as related to rhizosphere $\mathrm{pH}$,' European Journal of Soil Science, vol. 47, no. 4, pp. 533-544, 1996.

[50] T. C. Zhang and H. Pang, "Applications of microelectrode techniques to measure $\mathrm{pH}$ and oxidation-reduction potential in rhizosphere soil," Environmental Science and Technology, vol. 33, no. 8, pp. 1293-1299, 1999.

[51] V. Römheld and H. Marschner, "Plant-induced pH changes in the rhizosphere of ' $\mathrm{Fe}$-efficient' and ' $\mathrm{Fe}$-inefficient' soybean and corn cultivars," Journal of Plant Nutrition, vol. 7, no. 1-5, pp. 623-630, 2008.

[52] D. Riley and S. A. Barber, "Effect of ammonium and nitrate fertilization on phosphorus uptake as related to root-induced $\mathrm{pH}$ changes at the root-soil interface," Soil Science Society of America Journal, vol. 35, no. 2, pp. 301-306, 1971.

[53] D. A. Barber and K. B. Gunn, "The effect of mechanical forces on the exudation of organic substances by the roots of cereal plants grown under sterile conditions," New Phytologist, vol. 73, no. 1, pp. 39-45, 1974.

[54] D. L. Jones and P. R. Darrah, "Re-sorption of organic compounds by roots of Zea mays L. and its consequences in the rhizosphere. III. Characteristics of sugar influx and efflux," Plant and Soil, vol. 178, no. 1, pp. 153-160, 1996.

[55] B.-J. Koo, D. C. Adriano, N. S. Bolan, and C. D. Barton, "Root exudates and microorganisms," in Encyclopedia of Soils in the Environment, D. Hillel, Ed., vol. 3, pp. 421-428, Elsevier, Oxford, UK, 2005.

[56] D. C. Adriano, Trace Elements in Terrestrial Environments: Biogeochemistry, Bioavailability, and Risks of Metals, Springer, New York, NY, USA, 2nd edition, 2001.

[57] B.-J. Koo, W. Chen, A. C. Chang, A. L. Page, T. C. Granato, and R. H. Dowdy, "A root exudates based approach to assess the long-term phytoavailability of metals in biosolids-amended soils," Environmental Pollution, vol. 158, no. 8, pp. 2582-2588, 2010.

[58] C. Fernández-Ramos, O. Ballesteros, A. Zafra-Gómez et al., "Sorption and desorption of alcohol sulfate surfactants in an agricultural soil," Environmental Toxicology and Chemistry, vol. 33, no. 3, pp. 508-515, 2014.

[59] N. S. Bolan, D. C. Adriano, R. Natesan, and B.-J. Koo, "Effects of organic amendments on the reduction and phytoavailability of chromate in mineral soil," Journal of Environmental Quality, vol. 32, no. 1, pp. 120-128, 2003.

[60] S. P. Mishra, "Adsorption-desorption of heavy metal ions," Current Science, vol. 107, no. 4, pp. 601-612, 2014.

[61] S. A. Wasay, S. Barrington, S. Tokunagal, and S. Prasher, "Kinetics of heavy metal desorption from three soils using citric acid, tartaric acid, and EDTA," Journal of Environmental Engineering and Science, vol. 6, no. 6, pp. 611-622, 2007.

[62] J. Liu, J. Dai, R. Wang, F. Li, X. Du, and W. Wang, "Adsorption/ desorption and fate of mercury (II) by typical black soil and red soil in China," Soil and Sediment Contamination, vol. 19, no. 5, pp. 587-601, 2010. 

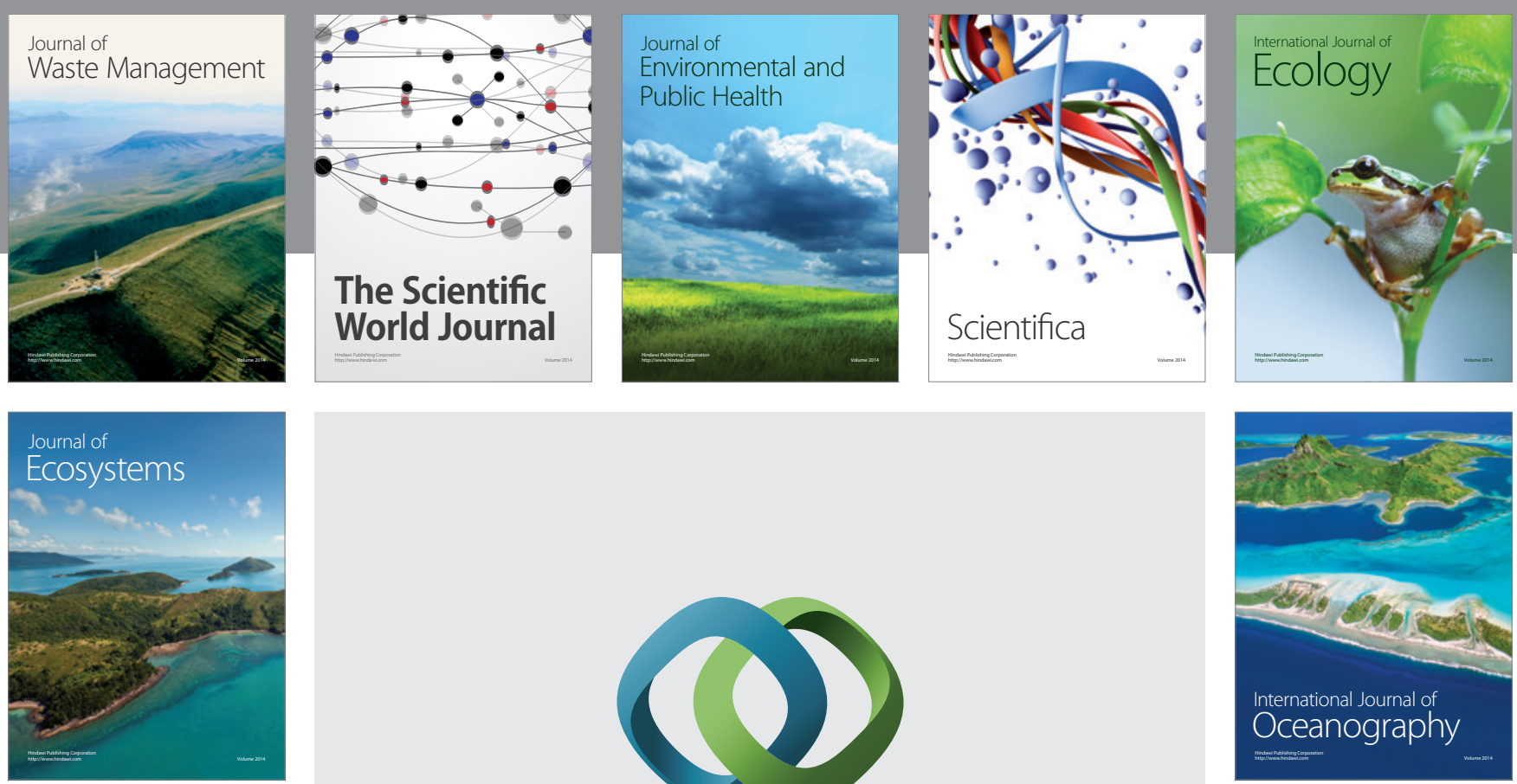

The Scientific World Journal
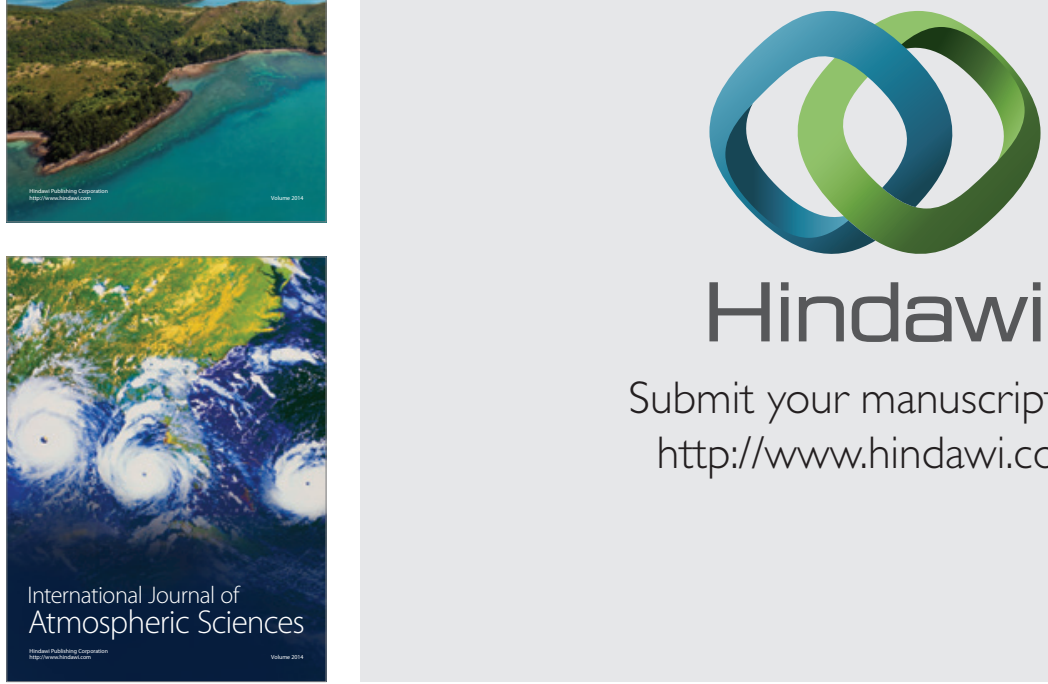

\section{Hindawi}

Submit your manuscripts at

http://www.hindawi.com
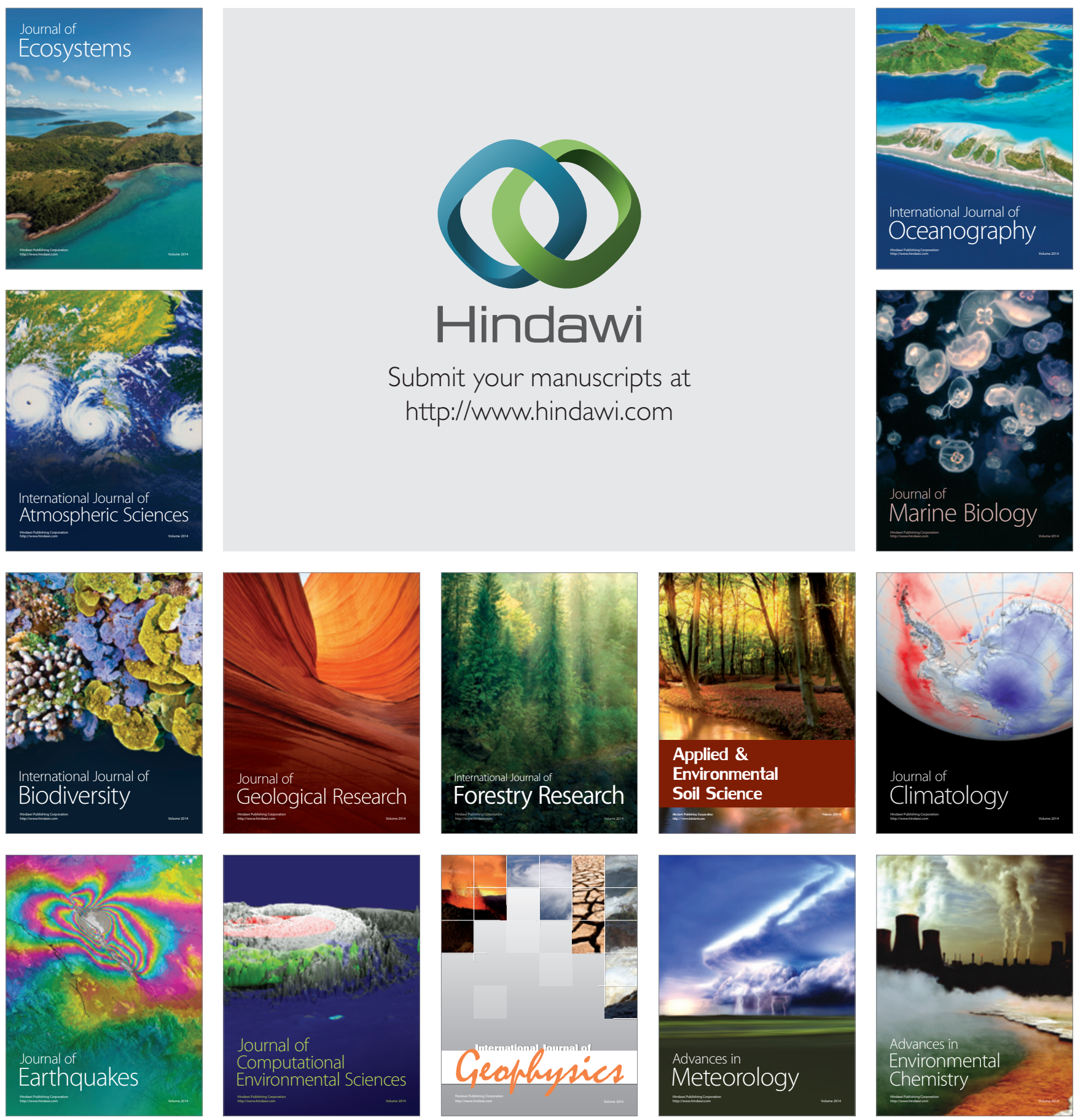